\title{
HIPPOCRATES THE IATROMECHANIST
}

\author{
by
}

\author{
IAIN M. LONIE*
}

\section{INTRODUCTION}

THE TITLE of this essay correctly indicates that it is about Hippocrates. Yet the content is largely concerned with the writings of Friedrich Hoffmann (1660-1742), Professor of Medicine and Physics at Halle from 1693 to 1742, and the author of an influential system of medicine. This requires some explanation. It is about Hippocrates, or the Hippocratic writings, in the sense that it seeks to identify the presence of certain features in them. It approaches this question, however, through the work of Hoffmann, whom it also seeks to understand in certain features of his thought. Hoffmann looked for, and found, characteristics in the Hippocratic corpus which matched those of his own medicine, a medicine which he called "mechanical". This suggests the main question with which the essay is concerned: to what extent are mechanistic features present in the Hippocratic corpus, and in what sense or senses of the word "mechanism"? Hoffmann both prompts this enquiry and maintains it in focus because, just as he is sensitive to some features, so he disregards others, curiously to my mind. In this way, he acts as a useful control upon our prejudices. So Hoffmann also becomes a subject of the essay, since we need to understand what he meant by mechanism, and why he found Hippocratic medicine congenial to it.

K. E. Rothschuh has recently pointed out that Hoffmann's position in the history of medical thought has always been difficult to locate. ${ }^{1}$ Historians have described him equally as a mechanist, an animist, or even as a vitalist. Several nineteenth-century historians fastened upon his acquaintance and correspondence ${ }^{2}$ with G. W. Leibniz,

* Iain M. Lonie, M.A., Wellcome Unit for the History of Medicine, Free School Lane, Cambridge CB2.3RF.

The work for this paper was made possible by the award of a Research Fellowship from the Wellcome Trust, for which I should like to express my gratitude. Earlier drafts were shown to Drs. Andrew Cunningham and Roger French (Wellcome Unit, Cambridge), Andrew Wear (Aberdeen), and James Longrigg (Newcastle upon Tyne). In the light of their extremely detailed and trenchant criticisms, it has been extensively rewritten, to its great benefit.

\footnotetext{
'K. E. Rothschuh, 'Studien zu Friedrich Hoffmann', Sudhoffs Arch., 1976, 60: 163-193, 235-270, with extensive citations from earlier literature. See in particular pp. 165-174 and his remark on p. 174: "Es gibt kaum einen bedeutenden medizinischen Autor der neueren Zeit, über den in der Fachliteratur so viele Meinungsverschiedenheiten bestehen wie über Hoffmann".

2 The correspondence is printed in Friderici Hoffmanni . . Opera omnia . . suppl. I, pars I, Geneva, Fratres de Tournes, 1749, pp. 49-56. The letters extend from 1699 to 1702, with a later one dated 1707. Most are about Hoffmann's observations and experiments upon atmospheric pressure, and other scientific matters. But the first is more general, arising out of a dissertation of Hoffmann's in which he had aligned himself with Leibniz's rejection of the Cartesian view that matter is passive. The last thanks Hoffmann for his assistance in the appointment to the Chair of Philosophy at Halle of Leibniz's disciple, Wolff.
} 
and took the influence of Leibniz upon Hoffmann's thought for granted, while others emphasized the Cartesian aspects of his mechanism. Rothschuh's study shows by example that the only satisfactory approach to such questions of influence is to subject particular doctrines professed by Hoffmann in physiology and pathology to a close textual examination. The present essay may be regarded as a contribution to this question, in respect not of any particular set of physiological or pathological doctrines held by him, but of his general concept of mechanism. Theodore Brown, ${ }^{3}$ examining iatromechanism in an English context, has shown the extreme importance of differentiating between Cartesian and Newtonian concepts of mechanism as they were applied to medicine in the seventeenth and eighteenth centuries. Some of the writers he discusses were explicit about the difference, and this explicitness was prompted, in their case, by institutional and social pressures. But with Hoffmann the situation is different. It will emerge that Hoffmann, who was above all a systematizer and a teacher, thought that all progressive tendencies in medicine since Harvey could be lumped together under the general rubric of a mechanical approach or method. But the truth, which to his mind justified this approach to medicine, was a concept of nature in which he was explicitly inspired by Leibniz, and which he also found in Hippocrates.

In the first section I outline Hoffmann's general attitude to recent and to Hippocratic medicine as it appears in the Prolegomena to his major work, the Medicina rationalis systematica. The second section is a provisional examination, conducted independently of Hoffmann, of various senses in which mechanistic attitudes can be identified in the Hippocratic corpus: the distinctions drawn here are intended to be of use in the final section. The third section returns briefly to Hoffmann, and makes the point that his approach to Hippocrates is conventional, even Galenic, to the extent that instead of looking for particular mechanistic features in Hippocrates, he starts from the assumption that there is a central conception of nature in Hippocratic medicine, which he identifies with his own conception. The final and longest section examines in the light of the preceding sections a dissertation in which Hoffmann argues in detail the case for seeing Hippocrates as a mechanist.

My general conclusions are, so far as Hippocrates is concerned, that there are mechanistic features in the Hippocratic corpus which approximate to some seventeenth- and eighteenth-century senses of mechanistic explanation in medicine, but that these tend to be compounded with animistic features. There is, however, one group of writings which attempts to exclude such features; and there is also an important sense in which Hippocratic therapy is governed by an approach to the body which is "mechanical" and analogous to that of the crafts. My conclusions about Hoffmann are two: his Leibnizean view of nature enabled him to find valuable confirmation of his mechanism in Hippocrates; and the structure of his interpretation of Hippocratic medicine is traditional in that it starts from a central conception of nature

${ }^{3}$ T. M. Brown, The mechanical philosophy and the 'animal economy' - a study in the development of English physiology in the 17th and early 18th century, Princeton University, Ph.D. dissertation, 1968. I am grateful to Dr. Andrew Cunningham for pointing out the relevance of this fine study to my thinking about iatromechanism. 


\section{Hippocrates the iatromechanist}

and ends with a practical medicine based on knowledge of the causes of health and disease in accordance with that conception.

\section{THE HISTORICAL SIGNIFICANCE OF HIPPOCRATES TO HOFFMANN}

In the Prolegomena to the Medicina rationalis systematica ${ }^{4}$ Friedrich Hoffmann in eight short and aphoristic chapters describes what he means by rational medicine, and he sets it in its philosophical and historical context. Borrowing a traditional definition, he says that medicine is "the science (scientia) of things healthy and unhealthy, by which science we preserve the human body in life and health, so far as this is possible, or restore it to health with the appropriate remedies." (MRS, Proleg., cap. I, §ii.) The indispensable foundation of this scientific knowledge is physics. But physics is not the nominalist physics of the scholastics, which explains nothing and substitutes empty names for real causes. It is that science which investigates the powers, properties, and effects of bodies by experiment, mechanical, chemical, and anatomical (ibid., §ix). The two supports of medicine are experience and reason: experience is the collection of many careful observations and their organization into complete and comprehensive case histories; while reason is the demonstration of effects through causes, which demonstration is rigorously deduced from certain principles in the manner of geometry. These principles are established by an accurate knowledge of anatomy and, again, physics (ibid., cap. II).

Hoffmann now places this rational medicine in its historical context (ibid., caps. III-IV). Medicine was at first empirical, but it was seen that experience alone was insufficient without the explanation of causes and their deduction from anatomy and physics. The founder and leader of this rationalist tendency in medicine was Hippocrates. But Galen introduced the principles of Aristotelian physics - the four elements, the temperaments, the qualities, and the humours - and so, under an unlucky star, was nominalist ${ }^{5}$ medicine born (ibid., cap. III, $\left.\$ \S i-v\right)$. Hoffmann continues with his survey through Paracelsus, Helmont, and the Cartesians. Paracelsus is rejected altogether; for Helmont, and for the Cartesians' efforts to establish a rational basis for medicine, Hoffmann expresses qualified approval, although his criticism of Helmont is severe. But the real change came with the discovery of the circulation (ibid., cap. III, §xii). Before this, there had been no solid basis for pathology, and hence, for therapy. The importance of Harvey's discovery was that it made possible the introduction of mechanics into medicine. For mechanics is the study of bodies in motion, and motion is the cause of all changes in bodies. The discovery of the circula-

\footnotetext{
4 Abbreviated hereinafter as MRS. It was originally published in two volumes in 1718-20. The edition which I have used is contained in vols. I-III of the Opera omnia physico-medica, Geneva, Fratres de Tournes, 1748. References will be to the volume, section, and chapter numbers of the MRS itself. References to Hippocratic texts will be by English title and, wherever possible, to the Loeb edition with Greek text and facing translation by W. H. S. Jones (Hippocrates. Works, Eng. trans. by W. H. S. Jones and E. T. Withington, vols. 1-4, London, Heinemann, 1923-1931). Other references will be to E. Littré, Oeuvres complètes d' Hippocrate, t. 1-10, Paris, Baillière, 1839-1861.

"In the scholion to III $\S v$, Hoffmann bluntly contrasts the "nominalist" medicine of Galen and the scholastics with the "realist" medicine of his own time. Nominalist medicine substitutes names and meaningless distinctions for the inquiry into true causes, and is the daughter of fancy; realist medicine is concerned with proximate causes and is experimental.
} 
tion showed that in the human body, too, motion is the fundamental principle of disease as well as of health.

Since the science of mechanics teaches and explains the disposition of bodies to motion and the nature, causes, and laws of this motion; and since the best physicians have learned to use principles and reasons drawn from mechanics in the explanation of causes, therefore this method of doing medicine is today called "mechanical”, and rightly so. (MRS, Proleg., cap. III, §xiii.)

This mechanical method of medicine, continues Hoffmann, which has been erected upon a foundation of anatomical and physical science, has been embraced by all the best men of the age - Borelli, Malpighi, Michelotti, Santorini, Ramazzini, Baglivi, Lancisi, Bianchi in Italy; Pitcairne, Freind, Keill, Albinus, and Boerhaave in Britain and Holland; Bohn, Brunner, Camerarius, Scheuchzer, Berger, Vater, Zwinger, Nebel, Paulli, and Schaper in Germany (ibid.).

Hoffmann did not describe himself as a iatromechanist - the term had not yet been invented, although it was just around the corner, ${ }^{6}$ and it would have sounded mildly pejorative - but he certainly professed, in the strongest terms, allegiance to a movement in medicine which he called mechanical. He identified it as beginning with Harvey and continuing up to himself and his immediate contemporaries. It was based on the science of mechanics. But whose mechanics? Or should we ask this question in Hoffmann's case? The roll-call of heroes which he offers includes a diversity of figures, in a manner which is apt to make the modern historian feel uneasy: Borelli and Malpighi on the one hand, the Newtonians Pitcairne, Freind and Keill on the other.? Yet this is evidently how Hoffmann viewed the matter; and his formulation is sufficient for his purposes in writing. He is after all writing about a general approach to medicine, or "method" as he calls it. Throughout the Prolegomena the emphasis is on progress: medicine has advanced spectacularly since Harvey: the cause of this advance is the application of mechanical reasoning and experiment in the discovery of proximate causes, as opposed to the "nominalist" medicine of Galen: all the outstanding medical men are in agreement over this. We do not know whether, for other purposes, Hoffmann might have drawn finer distinctions, or have been able to give a precise description of what he meant by the science of mechanics. ${ }^{8}$ What he immediately goes on to say in the Prolegomena indicates that his concern was over metaphysical positions rather than current issues in mathematical science. He describes those who are opposed to the mechanical medicine which he has been describing as those who

while unable to deny the artificial structure of parts in the body, yet consider matter and all bodies as passive in their own nature and without any motion or action, being merely the instruments of motion.... That principle which in man presides over life, health, and the cure of disease, they call nature or soul (anima) acting vitally; and they assert that its actions are more properly explained, not by mechanical principles and modes of action, but by a kind of moral judgement. (ibid., cap. III, §xiv.)

\footnotetext{
- Brown, op. cit., note 3 above, p. 122, n. 1, ascribes it to Haller.

' For the explicitly Newtonian programmes of these men, see ibid., chapters IV-VI.

- Some general propositions on motion are given in Fundamenta medicinae II, paragraphs 11-28; and ten laws of motion are stated in section xxxix of the De differentia doctrinae Stahlianae et Hoffmannianae (1742) (Opera omnia, suppl. I, pars 1, Geneva, 1749). In both cases these propositions and laws are very general.
} 


\section{Hippocrates the iatromechanist}

The language and the attitude which Hoffmann expresses here are repeated in his last published work, the controversy with Stahl.9 But they can be found as early as 1699 , in the dissertation De natura morborum medicatrice mechanica. ${ }^{10}$ In it Hoffmann had referred to a recent controversy in which Leibniz had attacked Sturm's Cartesian concept of matter as passive and inert. Hoffmann aligned himself with Leibniz, which prompted a friendly letter from the philosopher. ${ }^{11}$ In the scholion to the Prolegomena Hoffmann refers to his earlier dissertation, and he expresses the same allegiance in terms which clearly refer to Leibniz's view of matter:

The infinite power of God has produced active substances (substantias agentes) or substances endowed with active forces, which are the springs of operations and effects in others.... It is these forces which, by virtue of the effects they produce in other things; the mechanist observes, and the geometer measures....

On this matter, there was no change in Hoffmann's views from 1699 to 1742 , the date of the controversy with Stahl. And he could hardly make it clearer that the object of mechanical and mathematical study is Leibnizean nature.

This, then, is the context of Hoffmann's appraisal of mechanical medicine. Hoffmann now returns, after his triumphant demonstration of progress, to a more detailed historical survey. He begins with Hippocrates, to whom he devotes a whole chapter (Prolegomena, cap. IV). Here Hoffmann lists all of Hippocrates' works, describing what is of value in each. At their head he places collections of observations, for example the Epidemics, and the reduction of these observations to universal rules in the Aphorisms. These are followed by anatomy (Heart, Nature of bones, Fleshes, and others); in the third place comes natural philosophy (Breaths, Places in man, Nutriment, Airs, waters and places). Hippocrates too cultivated preventive medicine and hygiene (various texts on diet are cited here), and he was second to none in diagnosis and prognosis (the Aphorisms and the various collections of prognostic observations). He devoted himself also to surgery (Joints, Fractures, Wounds in the head); and finally he recommended the study of medical ethics (Oath. Decorum, Precepts). Hippocrates was the first to apply the principles of mechanics (mechanicae rationes) to medicine, for he explained health as the measure, proportion, and equilibrium of motions, and disease as their destruction. This can be seen in his work on Breaths, Regimen, and the Nature of man, but above all in his definition of

\footnotetext{
- See note 8 above. The work is discussed by Lester S. King, 'Stahl and Hoffmann: a study in eighteenth century animism', J. Hist. Med., 1964, 19: 118-130.

${ }^{10}$ To be found in Opera omnia, suppl. II, pars 1, Geneva, 1753, 551-562. After giving the Stoic view of matter (which he equates with that held by Spinoza), and the Cartesian view, Hoffmann describes what seems to him both probable and pious: "God composed bodies neither out of an active spiritual substance and one which was passive; nor out of one which was purely passive, which he then aroused to motion and animated; but rather at the beginning of creation he produced substances, or forces with extension, which were capable of movement, either communicating to other things their own internal active force or by themselves receiving force from other things".

"See note 2 above. Leibniz praises Hoffmann for his rejection of the Cartesian view. The Cartesians, he says, leap too immediately to first principles: there should be more men like Hoffmann, who are prepared to proceed gradually and to investigate proximate causes. If Hoffmann goes on as he has begun, Leibniz and Germany too will be in his debt.
} 
mechanical medicine, in Breaths, as "the addition of what is lacking and the subtraction of what is in excess". That he knew of the circulation of the blood can also be proved, says Hoffmann, from various texts, such as Nutriment, Dreams, and Breaths.

Thus Hippocrates laid the foundations of a "solid" medicine, and it is a matter for surprise that the art has not progressed further in the many centuries since his time. But the reason lies in the adoption of a perverse method of philosophy according to the precepts of Aristotle, instead of the enrichment of medicine by a wealth of observations and new discoveries. It was therefore Hoffmann's task to follow the course set by Hippocrates, and to advance the art (i) by accurate histories of diseases; (ii) by careful anatomical observations; (iii) by the aid of a solid experimental physics, including both mechanical and chemical experiments (ibid., cap. V, $\S \S \mathrm{i}$-iii).

Rational medicine began with Hippocrates; if it is to advance, it must be by the Hippocratic way. This idea is not surprising when we encounter it in a writer of the sixteenth century: medicine had been led astray by the Arabs and the medieval Latin writers, and must be restored by a return to the true method laid down by Hippocrates, interpreted by Galen, and now available once again in the newly edited texts of antiquity. But by Hoffmann's time these texts were no longer new; their role in teaching had begun to diminish; and the face of medicine had been very much altered by anatomical and physiological research. The writers of the time were conscious of these changes, and explicit about them; and although the attitude to Hippocrates expressed by Hoffmann is by no means uncommon in writing of the time, ${ }^{12}$ it is not easy to reconcile with this consciousness of change. Occasionally such an appeal may be mere fashionable rhetoric; but often enough it is authenticated by detailed references to Hippocrates, and by new editions of and new commentaries upon certain parts of the Hippocratic corpus. The reasons for the eighteenth-century investment in Hippocrates is a large and complex subject, which has not yet been systematically investigated. But some observations may be made. It is not sufficient to point to the fact (which is in itself interesting) that certain Hippocratic texts were capable of reinterpretation in the light of whatever theories were fashionable; for this leaves

\footnotetext{
12 The most celebrated passage occurs in Thomas Willis's preface to De febribus, whereby the only way to restore the edifice of medicine, which the discovery of Harvey has caused to collapse, is by following the example of meticulous observation set by Hippocrates: "And if led by the Example of Hippocrates, his Followers had only polished his Observations and Experiments, without doubt the Medicinal Art had grown up better, more handsomely, and with greater benefit to the Sick ..." (cf. Works, tr. S. Pordage, London, Dring, 1684, p. 45). Willis's preface may be the source for this idea in subsequent writers. It is expressed seeveral times by Giorgio Baglivi (cf. e.g. his preface to the Praxis medica. Opera omnia medicopractica et anatomica, Venice, J. Tomasinus, 1716); and it is crucial to his complicated attempt to reconcile modern physiological experimentation with a medicine which should be devoid of "hypotheses" and rest purely on the recording of histories in the Hippocratic manner. After Baglivi we find it clearly expressed in Boerhaave and his commentator, van Swieten: "Those who to the correct observations of the ancients join the discoveries of the moderns, seem to lay the best foundations for raising a just superstructure" (G. van Swieten, Commentaria in Hermanni Boerhaave Aphorismos, Leiden, Verbeek, 1745-1772, vol. 1 (1745), p. 6). Van Swieten has just asked the question why so many modern discoveries have contributed so little to the actual progress of practical medicine. The name of Sydenham occurs frequently in such contexts: cf. John Barker, An essay on the agreement betwixt ancient and modern physicians, London, G. Hawkins, 1748, p. 175: "Thus the Helmontian theory, and that of Sylvius, Willis, and the Cartesians, each triumphed in its turn; till at length Sydenham's Method prevailed, and Medicine, which for some years back had been in a fluctuating state, was settled again upon the old Foundations."
} 


\section{Hippocrates the iatromechanist}

unanswered the question why writers thought it worth their while to do this. It is more relevant to point to the nature of the texts which were treated in this way. They tended to be the Aphorisms, Epidemics, and the prognostic texts: that is, those concerned with diagnosis, prognosis, and general principles of treatment. What they have in common is a generalized humoralism, and the theory that acute and particularly febrile acute diseases show a process of "concoction", "crisis", and expulsion of morbid material. This humoralism often continued to provide the structure within which diseases were described, and treated, in the seventeenth and eighteenth centuries. The processes of concoction and crisis were explained in various ways, and the terms themselves were sometimes apologized for as ancient locutions which nevertheless referred to real events. But few medical writers, apart from Paracelsians, were prepared to discard the structure altogether. ${ }^{13}$ In particular details of treatment, both practice and the terms in which it was justified, might vary widely from one physician to another. Yet below, and not too far below, the level of these particular differences, treatments tend to look much the same, and debates about treatment could be conducted in a common language.

In view of this tendency to retain the traditional structure of humoralism, it is not surprising that writers should have devoted some of their energies to re-interpreting the traditional texts. During the eighteenth century a series of commentaries upon the Aphorisms appeared in which Hippocratic doctrines were glossed with the terminology of modern medicine, and therefore shown to be relevant. ${ }^{14}$ The device which makes this possible is the retention in modified forms, and with new explanations, of the doctrines of coction and crisis, and of innate or vital heat. The general attitude behind this manoeuvre is expressed perfectly by the author of one of these commentaries, Philippe Hecquet (1661-1737). In his introduction, Hecquet says simply:

La médecine moderne se trouve aussi d'avance confirmée par l'ancienne, puisque la moderne n'est veritable qu'autant que celle des premiers tems a été heureusement inventée et pratiquée avec succes: et la cause de la vérité de la moderne, ne vient que de ce qu'elle a découvert les causes du succes de l'ancienne. ${ }^{13}$

The second part of Hecquet's statement is exemplified by the way in which some

\footnotetext{
${ }^{13}$ Baglivi simply said: "I cure my fever cases by the laws of coctions and crises as Hippocrates has demonstrated them to me" (De fibra motrice, ch. 13, p. 251). This from a man who believed that Hippocratic therapy was aimed at the solids rather than the humours. The mechanists had no difficulty in accommodating the doctrine, and indeed seem to welcome the opportunity of doing so. A convenient survey of views is given by J. C. Rieger (Hippocratis Coi Aphorismi notationibus variorum illustrati, The Hague, P. van Clef, 1767), in commenting upon Aph. 1. 22. Boerhaave (Praelectiones acadenticae, ed. A. von Haller, Amsterdam, J. Wetstenius, 1739-1744, \$921-957) is exceptional only in the length and detail with which he reformulates and justifies the traditional doctrine. He regarded it as essential for prognosis, and also for therapy, which in Boerhaave is closely related to prognosis. Hoffmann too accepted the doctrine: see especially De crisium natura eiusque explicatione rationali (Opera omnia, vol. VI, 173-181).

${ }^{14} \mathrm{C}$. J. Sprengell, The aphorisms of Hippocrates, London, R. Bonwick et al., 1708. Philippe Hecquet, Les Aphorismes d'Hippocrate, expliquez conformément au sens de l'auteur à la practique médecinale et à la méchanique du corps humain, Paris, 1727. J. de Gorter, Medicina Hippocratica exponens aphorismos Hippocratis, Amsterdam, J. Ratelband, 1739-42. J. C. Rieger, Hippocratis Coi aphorismi notationibus variorum illustrati, The Hague, P. van Clef, 1767. A. C. Lorry, Hippocratis aphorismi, Hippocratis et Celsi locis parallelis illustrati, studio et cura Jasonii ab Almeloveen . . Loca parallela ex Boerhavii Commentariis ... addidit Anna Car. Lorry, Paris, Barrois, 1784.

${ }^{13}$ Hecquet, op. cit., note 14 above, $A$ vant-propos, xxxvii.
} 


\section{Iain M. Lonie}

iatromechanists explicitly sought confirmation for their physiological and pathological theories in their competence to account for features in traditional nosology and therapy. This was the strategy adopted by Bellini in recommending his mechanist account of fevers. ${ }^{16}$

But there was another characteristic, distinct from their humoralism though ultimately based upon it, which may have contributed to the survival of these texts. They were a rich storehouse of facts and predictions, generally regarded as true, concerning particular diseases; and they also contained a number of therapeutic principles, whose value lay in their high level of generality. It may be assumed that the practical physician - if he was one of the better educated of his class - had floating around in his mind a number of diagnostic, prognostic, and therapeutic observations, numerous and varied enough to match the variety of situations which he was likely to encounter in practice. These observations would be detailed and particular; they would not necessarily be systematically connected; and they would be useless unless they could be promptly retrieved - that is to say, they must be carried in the memory. These are characteristics of craft knowledge as opposed to systematic knowledge. Any craft will include an indefinite number of observations and maxims, the means which the craftsman uses to assess all the aspects of a practical situation, and so to determine the procedure he will take. ${ }^{17}$ In most crafts, these rules and cases never reach conscious, let alone literate, expression; and even in technical instruction they are passed on by demonstration, and orally rather than literarily. But in medicine they did reach literate expression. The intensity of the use which the physician made of them can only be assessed by a study of practical texts from the sixteenth century on, particularly medical observations, consultations or consilia, and treatises on particular diseases. The general impression which such texts give is that, despite their conscious effort at untrammelled observation, the details which the physician chooses to observe are very often determined by the emphasis which the same details receive in Hippocratic texts. If this impression is correct, it suggests that there was an intimate connexion between the practical physician's craft knowledge and such texts. Theories in medicine which maintained the validity of this diagnostic, prognostic, and therapeutic detail would, then, be particularly welcome. Medicine could be updated without the risks involved in serious modification, or discarding, of its detailed practical content.

These are offered as suggestions only, although I believe that they can be supported by examination of the sources. However, they affect Hoffmann's milieu rather than

${ }^{16}$ L. Bellini, De urinis et pulsibus, de missione sanguinis, de febribus, etc., Bologna, heirs of A. Pisarrius, 1683. Although Bellini rejects the traditional classification of fevers into ephemeral, putrid, and hectic, on the grounds that it carries implications about the causes of fever, his actual procedure consists in demonstrating that the antecedents, concomitants, and consequences of all fevers as they are described in the traditional textbooks can be accounted for by his theory.

17 The physicians themselves stressed the variety of circumstances which they were likely to meet, one irreducible to any general formula. This had the double advantage of protecting the arcana of their craft, and providing them with a ready excuse for the failure of treatment in any particular case. It was also a part of the traditional description of Hippocratic "rational" medicine that it took into account a wide range of individual factors - age, sex, constitution, manner of life, the season, the weather. $\mathrm{Cf}$. the description of the rational sect in Galen, De sectis ad eos qui introducuntur, C. G. Kühn (editor), Galen. Opera omnia, 20 vols., Leipzig, Cnobloch, 1821-33 [hereinafter cited as K.], 3, I, 69K. 


\section{Hippocrates the iatromechanist}

Hoffmann himself. They explain the kind of resonance which he obviously expected from his claim that the best modern medicine is Hippocratic medicine. But Hoffmann supports this claim directly, by an appeal to Hippocrates' "physical" texts - not indirectly, by an appeal to Hippocratic observations, as confirming, by their accuracy, the truth of modern theory. For Hoffmann, the most significant characteristics of modern medicine - its basis in anatomy and physics, its use of mechanical reasoning, and the central position given to the circulation - had already been at least adumbrated in the writings of Hippocrates.

\section{HIPPOCRATES THE IATROMECHANIST}

As we have seen, Hoffmann was neither the first nor the last to enlist Hippocrates in the service of "progressive" tendencies in medicine. But that Hippocrates could plausibly be so enlisted is due to another circumstance: the extremely heterogeneous nature of the texts in the Hippocratic collection.

It is a commonplace of Hippocratic scholarship today that these texts were written by different authors, express the attitudes of different groups of physicians, and even originate in different periods of Greek medicine. But the close analysis of these differences conducted with the purpose of assigning texts to different groups or periods, is a comparatively recent development. ${ }^{18}$ The related (and unanswerable) question of which texts are "genuinely" by Hippocrates, and which are not, is much older. Medical writers from the sixteenth century on were perfectly aware that not all the texts in the Hippocratic collection were written by the same author. But despite the work of Lemos, Mercuriali, Foes, and others, ${ }^{19}$ it is a question which does not seem to have been regarded as very important for practical purposes, even by the scholars who investigated it. "Hippocrates" and the Hippocratic collection were regarded as more or less coextensive, and although a writer in citing a text as authority might remark that it was thought not to be by Hippocrates, he would cite it none the less. Furthermore, these writers were able to tolerate or even ignore a quite surprising amount of contradiction between texts. In the end, what outweighed all such difficulties was the impressive title-page, which attributed all these texts to Hippocrates of Cos - "the Great".

\footnotetext{
1s See Littré, op. cit., note 4 above, tom. 1, ch. viii, pp. 169-199, where the history of this scholarship is traced; on the tradition in general, Wesley D. Smith, The Hippocratic tradition, Ithaca and London, Cornell University Press, 1979, esp. ch. 1; on a particular aspect of the tradition, I. M. Lonie, 'Cos versus Cnidus and the historians', Hist. Sci., 1978, 16: 42-75, 77-92. It was not until comparatively late that a serious attempt was made to classify the texts according to systematic doctrinal differences, although it is these which are most likely to strike the modern reader.

19 L. Lemos, Judicium operum magni Hippocratis, Salamanca, 1588, republished Meissen, Klinkicht, 1835; Hippocratis opera quae extant ... a Hieron. Mercuriali, Venice, Junta, 1588; Hippocratis opera omnia quae exstant ... Anutio Foesio auctore, Frankfurt, heirs of A. Wechsel, 1595. Mercuriali's Censura operum Hippocratis is prefixed to his edition, in which the texts are actually printed in the order of his classification. Foes's observations are found in his annotations to each text. Remarks on the subject are made by many subsequent medical writers, particularly by Haller in his bibliographies. The general attitude to the question was perhaps that taken by Foes, who while praising Mercuriali, believes that the traditional arrangement of the texts is the most convenient for reference, since these books, he says, are not to be read only in the study, but by the patient's bedside as well (see his dedicatory epistle to the Paris faculty). Hippocrates, as always, is to be valued for his practical use.
} 


\section{Iain M. Lonie}

Hoffmann, too, quotes extensively from the whole range of texts in the collection. Quotations from the Aphorisms, the prognostic works, and the Epidemics are particularly common, as one would expect in the later volumes of the MRS, which are concerned with the pathology and treatment of particular diseases. ${ }^{20}$ But in the earlier volumes, which deal with physiology, pathology, hygiene, and general principles of therapy, he quotes repeatedly from a selection of favourite texts, listed in MRS tom. II, Proleg., cap. I, §xv. The Ancients, he says, particularly Hippocrates, recognized the value for medicine of the study of physics, as witness Hippocrates' physical works Nature of man, Heart, Places in man, Breaths, Regimen, and Airs, waters and places. Hoffmann's point here is a general one, which these texts, and several others which he might have cited, illustrate sufficiently well. They are all "physical" in the sense that they attempt to identify the processes which occur in the body in health and in disease; they give a causal account of these processes; these accounts are expressed in terms of things and events which can be observed in the physical world at large; and finally these processes occur within a more or less vaguely conceived anatomy of organs and communicating vessels traversed by fluids.

Hoffmann quotes from these texts, partly because they deal with topics which interest him (especially anatomy, the environment, and diet), and partly because they contain particular passages which he found relevant to his conception of medicine. For both reasons these texts encouraged him in the belief that Hippocratic medicine was "mechanical", and that Hippocrates was the first to employ mechanistic principles (mechanicae rationes) in medicine. To what extent is such mechanistic reasoning present in Hippocratic writings?

Hoffmann appears to use the phrase mechanicae rationes in two ways. In a strict sense he means the application of the science of mechanics, the laws of bodies in motion, to particular physiological and pathological processes. This application is mathematical or "geometrical" in form. ${ }^{21}$ But he also seems to regard as a mechanistic explanation one which is delivered in terms of the impact, or of the continuous contact and pressure, of solid and fluid bodies upon each other. Although the concept of motion is basic to this kind of explanation, it is not necessarily a direct application of the laws of mechanics, nor is it expressed in mathematical form. For example, in illustrating the way in which mechanical causes may be said to operate in the body, he writes:

That motion by which all that occurs in our body is accomplished, and which the physician must use in demonstration, is none other than contraction and expansion or, as the Greeks called it, the systole and diastole, of the nervous and muscular fibres and of the heart, the arteries, and all channels which are woven together from these fibres. It is by the agency of this movement that fluids of every kind are impelled in circulation through innumerable different channels, and what is useful in these fluids is secreted and retained, while what is useless is excreted. (Proleg., cap. VIII, §xi.)

\footnotetext{
${ }^{20}$ However, quotations from the later authors, particularly Aretaeus, Alexander of Tralles, Paul of Aegina, Celsus, and Caelius Aurelianus are equally common; and quotations from modern collections of medical observations preponderate. This is what one would expect.

${ }^{21}$ Dissertatio de medicina Hippocratis mechanica (1719) (suppl. 2, pars 1), §II (this dissertation will be discussed in detail below); and for the general desirability of a mathematical method in medicine, "proceeding syllogistically from indubitable principles", cf. MRS, Proleg., cap. II, §x; cap. VIII, §i.
} 


\section{Hippocrates the iatromechanist}

These two senses were not ultimately distinct for Hoffmann, since all motion and change of this kind was theoretically capable of reduction to the laws of mechanics and of mathematical expression. But he nowhere gives an example of a mathematically expressed physiological law; and the fact that such expression remains in the realm of theoretical possibility makes it easier for him to describe both his own medicine, and that of Hippocrates, as mechanical.

The difficulty in attempting to decide to what extent Hippocratic explanation is mechanistic, is that the word "mechanism" is itself vague and ambiguous, as the above example shows. ${ }^{22}$ In one sense, a mechanistic explanation is one which involves the mathematical application of the science of mechanics to bodies in motion; but in a second, equally valid sense, it is one which, without such application, is delivered in terms of the mutual contact and pressure of bodies, both solid and fluid. To these two senses we may add a third: we label "mechanistic" an explanation which is modelled upon the working of machines or automata.

These three senses are not mutually exclusive, and the second and third have a derivative, or a potential, relation to the first or strict sense. But because of the archaic nature of the Hippocratic writings, in which what we might regard as quite different modes of explanation may exist side by side, we need to make a further distinction. An explanation may, and in Hippocratic texts frequently does, include some features which are animistic rather than mechanistic. We may choose to disregard these features, if they are minor, and still describe the explanation as mechanistic. But there may also be explanations which explicitly or implicitly exclude animistic features, in conscious fulfilment of a programme to reduce all physical explanations to mechanistic terms. Here "mechanistic" refers to the attitude in which the explanation is offered, as well as to the explanation itself. As we shall see, there are passages in certain Hippocratic writings which justify this distinction. Finally, the presence in the Hippocratic writings of texts concerned with dietetics and therapy requires us to identify another sense, in which a mechanistic explanation is one which is expressed in terms of commensurable quantities, and their equilibrium, imbalance, and displacement.

It is not difficult to find mechanistic tendencies in Hippocratic texts in each of these senses, except the first. This has to be excluded, since there was nothing at the time which we could regard as a science of mechanics with coherently formulated laws. ${ }^{23}$

\footnotetext{
${ }^{22}$ On the ambiguities of the word, see E. J. Dijksterhuis (The mechanization of the world picture, trans. C. Dikshoorn, Oxford, Clarendon Press, 1961, pp. 4, 495-501), who distinguishes the view that the world is a "machine" from the belief that "natural events can be described with the aid of the concepts and dealt with by the methods of a branch of science that is called mechanics" (p. 4). Hoffmann uses the word in both senses. See also The new Catholic encyclopedia, New York, McGraw-Hill, 1967, vol. 9, s.v. 'Mechanism'; "Mechanism attempts to explain the physical world by the movement of inert bodies that are pushed or pulled through direct or indirect physical contact with other bodies. Its proponents often hold that local motion is the only real motion, and that a body is maintained in such motion by its own inertia or impetus. Again, they frequently reduce physical bodies to purely quantitative principles, thereby giving mathematics primacy in physical science." The author of the article, taking this as the basic meaning, mentions the Greek atomists as the earliest proponents of a mechanistic view of the world.

${ }^{23}$ The Pythagorean philospher Archytas of Tarentum (fl. 370 B.C.) is said to have been the first to apply mathematical principles to the study of mechanics (Diogenes Laertius, Vitae philosophorum, VIII, 83). The application of mechanics to man would also have required a body of anatomical and physiological facts which the Greeks did not then possess.
} 


\section{Iain M. Lonie}

But there are very many explanations of bodily processes which are mechanistic in the second, general sense. Indeed, the whole humoral theory which, with individual variations, all these texts hold in common, might be so described. In the humoral theory health, disease, and the influence of the environment are explained in terms of a diversity of humours which move around the body through a system of interconnected vessels. These humours may alter in consistency through the effects of heat, cold, and movement; they may obstruct the passage of other humours or of air by coagulating or compacting; or they may assemble in too great quantity in particular organs or parts of the body. Since this is a system in which fluids move through tubes and may exert pressure upon or suffer pressure from their containing vessels, it is recognizably mechanistic in at least one sense. The particular explanations which it allows bear a strong resemblance to the kind of explanations, particularly pathological ones, given by Hoffmann and other iatromechanist writers. The proportion of such explanations in the Hippocratic collection is very high, ${ }^{24}$ but I shall give only two illustrations, each taken from a favourite text of Hoffmann's. In Breaths 8 (VI, 100-104 Li.) the author explains various symptoms in fever. Shivering occurs because the blood, "fearing" chill, runs together from all the extremities of the body to its hottest parts, the viscera. The impact of this large quantity of blood arriving together causes them to shake, while the extremities also shiver because they are cold. Yawning in fever occurs because the accumulated air within the body, which is the basic cause of fever, rises upwards and "levers" the mouth open. This motion of the air upwards is like the rising of steam from a boiling cauldron, and is similarly caused by heat. The air is heated by the blood, and conveys its heat through the whole body, and this is the cause of febrile heat (this explanation or a form of it became canonized in Galen, and was preserved in fever theory up to the end of the eighteenth century). ${ }^{25}$ The overheated blood vaporizes; this vapour passes through the pores where it condenses again on contact with cold air, "in the same way that steam rising from boiling water condenses and forms into drops when it encounters the solid surface of the lid." Pains and throbbing in the head are explained by distention of the veins caused by high air pressure. ${ }^{26}$

This passage is typical of many in the collection. The combination of animistic (the blood "runs away" from the cold) with mechanistic (particularly the "levering" open of the jaws by the air) features is characteristic; so is the comparison with condensing steam; and the general use of such concepts as impact, condensation, and pressure.

\footnotetext{
24 They occur principally in the following texts: Airs, waters and places (Jones 1, 70-137); Affections (VI, 208-271 Li.); Regimen (Jones 4, 224-447); Breaths (Jones 2, 226-253); Places in man (VI, 276-349 Li.); Diseases 2, 1-11 (VII, 8-18 Li.); Sacred disease (Jones 2, 138-183); Diseases of women 1 (VIII, 10-233 Li.); Seed, Nature of the child, and Diseases 4 (VII, 470-615 Li.). These texts vary in the explicitness and the frequency with which such explanations are used.

${ }^{2 s}$ Galen, De febrium differentiis (VII, 273-405 K.): fever is preternatural heat, either in the pneuma (in "ephemeral" fevers), the humours ("putrid" fevers), or the solid parts of the body ("hectic" fevers). But the state of fever actually arises when the heat is conveyed to the heart, either in the form of pneuma heated by the blood or of a "sooty vapour" which arises from putrid humours. See especially De febrium differentiis, I. 7 (VII, 294-300 K.).

${ }^{26}$ The whole passage from Breaths was quoted by Hoffmann in the Tractatio brevis et luculenta de febribus (suppl. I, pars 1, p. 301) to show that his definition of the essence of fever as "an irregularity in the progressive circulatory movement of the blood" was not novel, but had occurred to the most ancient and wisest of physicians.
} 


\section{Hippocrates the iatromechanist}

The second passage is from Regimen 2.66 (Jones 4, 360-361).

Now if the secretion prove abundant it overpowers even that which is healthy, so that the whole body is heated and a high fever follows. For when the blood has been attracted and heated, the things in the body set up a rapid circulation, and the body generally is cleansed by the breath, while the collected moisture, becoming warm, is thinned and forced outwards from the flesh to the skin, and is called "hot sweat". When the secretion of this is over, the blood is restored to its natural motion, the fever subsides, and the fatigue pains cease about the third day. (Trans. Jones.)

With very little change, one might find this passage in almost any account of fever in the seventeenth and eighteenth centuries. The fever is of a kind which was called "ephemeral" in the later tradition. To a mechanist writer of the seventeenth century the account in Regimen might have seemed gratifyingly "modern". He would have noted the apparent recognition of the circulation, the association of fever with accelerated circulation, and the attribution of a vis medicatrix to this acceleration. This attribution is commonplace in mechanistic medical thought. ${ }^{27}$ Yet the passage is thoroughly "Hippocratic", e.g., in the idea that the peccant humour "overpowers" the healthy humour.

The third sense of mechanism, according to which a mechanistic explanation is one in which a natural process is described in terms of the working of a machine or an automaton, does not as such occur in the Hippocratic collection. There is certainly nothing like the full-scale pneumatic model which is presented in Descartes' treatise on man. ${ }^{28}$ Most of these texts were written in an age which was technologically primitive to an extent which we find hard to imagine. Hence the materials, and to some extent the mood, for such comparisons did not exist until the technically inventive Hellenistic period. Although some texts in the collection may be as late as this in date, they show no sign of such an influence by technology..$^{29}$

\footnotetext{
${ }^{27}$ After Harvey's discovery the heat and increased pulse rate in fever were automatically associated with accelerated circulation. Boerhaave, for example, identified fever with accelerated circulation (Aphorismi de cognoscendis et curandis morbis, Leiden, Van der Linden, 1709, §587) and the circulation with "vis naturae" or "vis vitae" (Institutiones medicinae, 5th ed., Leiden, Van der Linden, 1734, \$918; Praelectiones academica (= Dr. Boerhaave's academical lectures on the theory of physic, 3rd ed., London, 1766, p. 1166, n. 2); the circulation concocts the humours (Inst. med., op. cit., \$929); hence Boerhaave's adoption of Sydenham's views on the curative powers of fever is automatic (Aphorismi, op. cit., §588, §589; van Swieten on $\$ 587$ cites Sydenham, Med. obs., I, 4 (G. van Swieten, Commentaria in Hermanni Boerhaave Aphorismos, op. cit., note 12 above, vol. 2 (1749), p. 50.)). For Hoffmann's views on fever, see below, pp. 146-147.

22 Treatise of man: French text with translation and commentary by T. S. Hall, Boston, Mass., Harvard University Press, 1972.

29 For the technological problems in Heart (which probably belongs in the early Hellenistic period), see what I have said in Med. Hist., 1973, 17: 143-146. The tendency to find resemblances between parts of the body and technological implements was fostered in Greek science by teleology. This is found as early as the fifth century B.C. in Diogenes of Apollonia (see W. Theiler, Zur Geschichte der teleologischen Naturbetrachtung bis auf Aristoteles, Zürich, and Leipzig, 1925, p. 6ff.) and is continued by Plato in the Timaeus where the approach is overtly teleological. A passage in Galen underlines the connexion between teleology and the sense of mechanism which we are discussing here. In De usu partium, 4, 2, (III, $268 \mathrm{~K}$.) he urges the reader to believe that "in the living body nothing is without function or unmoved, but all parts have their appropriate arrangement, since the Creator has endowed them with divine powers"; and he compares the body to the "self-moving" (Autokinèta) constructions of the god Hephaistos, the bellows which started to work themselves at the god's command, and the serving maids of gold who "moved of their own accord like their master himself".
} 


\section{Iain M. Lonie}

Yet there are certain foreshadowings which suggest that such a model as that of Descartes was not altogether remote from this period. Those Hippocratic writers who attempt to explain physiological processes often resort to physical models for illustrative analogies of the invisible processes which occur in the body. Many of these models are themselves natural processes, such as atmospheric phenomena of condensation or evaporation, or the burning of a flame used to illustrate respiration. But some make use of technical implements, or of technological processes. The most striking of these comparisons occur in the texts Nature of the child and Diseases 4, and also in Regimen 1, 12-24 (which will be discussed on p. 150). In Ancient medicine $22^{30}$ there is an interesting attempt to explain the functional efficiency of organs in the body by their shape and composition. For example those which are wide and hollow but taper to a narrow neck are efficient at drawing in fluids. Such are the bladder, the head, and the uterus, and the author illustrates their action by comparing them to the physician's narrow-necked cupping-glass, which, he remarks, has been artificially contrived for this purpose (Tetechneatai). ${ }^{31}$

Such passages are as far as the Hippocratic writers go in the direction of this kind of mechanism; and they concern particular organs or processes rather than the working of the body as a whole. The full-scale comparison of man to a machine in the seventeenth century was a product of philosophical discussion about the relation of the soul to the body. Hippocratic writers show little direct interest in this question: the philosophers, however, did. In a passage in the De anima, ${ }^{32}$ Aristotle compares the way in which Democritus imagined the soul to move the body to the mythical statue of Aphrodite which Daedalus was said to have caused to move by pouring quicksilver into it. It is Aristotle who makes the comparison, and not Democritus; but it is interesting that it should have been suggested by the views about the soul of Democritus, whose attitude is the most markedly mechanistic of all the early Greek philosophers. But it is in Aristotle himself that the comparison of animate movement to the movements of automata first occurs. In the treatise on the Movement of animals 7 he compares the way in which a desire or thought is transformed into physical action to "automata" which require only a small initial movement to set their mechanism going. ${ }^{33}$ This mechanism evidently works by the release of torsion, and Aristotle compares the twisted strings (streblai) of these toys to the neura (=muscles and tendons) in animals. ${ }^{34}$ In this treatise, and still more in the related Progression of animals, Aristotle is largely concerned with the physical factors necessary for animate movement, and he occasionally gives them geometric expression. Such passages might

\footnotetext{
30 Jones $1.56-61$. The author's purpose is not, however, to introduce a mechanistic physiology, but to explain by analogy the effects of the shape of organs in causing disease. The mechanism is latent.

${ }^{31}$ The comparison of the head to a cupping-glass also occurs in Diseases 4, 35 (VII, $548 \mathrm{Li}$.) and is implicit in Diseases 1, 15 (VI, $168 \mathrm{Li}$.).

${ }^{32}$ De Anima 406b15. Cf. the serving maids of Hephaistos mentioned by Galen (note 29 above).

${ }^{33}$ Aristotle uses the same comparison in Generation of animals $734 \mathrm{~b} 10-16$ and $741 \mathrm{~b} 9$ to illustrate the way in which a small initial movement in the semen activates the whole process of development in the embryo.

${ }^{34} \mathrm{He}$ adds that while in automata the moving parts remain the same, "in the animal the same part can become both greater and smaller and change in shape, the members increasing through heat and contracting again through cold, and thus altering" (701b14-16).
} 


\section{Hippocrates the iatromechanist}

conceivably have been developed into a systematic application of mechanics to animate movement. ${ }^{35}$

Finally, the technology which might have suggested a fruitful exploration of Aristotle's comparison was developed in the Hellenistic era. The Construction of automata of Hero of Alexandria describes the theory and construction of a model theatre, including figures which "can be made to move individually and use saws or adzes or mallets if the plot requires it". ${ }^{36}$

The mechanistic features in the Hippocratic collection which I have so far discussed exist alongside other features which we would hesitate to describe as mechanistic, and most of the writers concerned do not seem to be aware of any distinction between mechanistic and non-mechanistic types of explanation. This is partly a consequence of the humoral theory itself. Hoffmann objected to Galenic and scholastic medicine because it explained in terms of "qualities" rather than of real things. ${ }^{37}$ But this tendency, of course, already existed in the Hippocratic humoral system. Whatever the origins of the belief in humours as factors in disease, it had at some early stage become associated with the habitual Greek tendency to think in terms of unreduced qualitative opposites. Broadly speaking, humoral explanations tend towards mechanism so far as they are quantitative: but they often call upon faculties and qualities which remain unreduced to other terms.

Such a mixture of mechanistic and non-mechanistic types of explanation is characteristic of pre-Socratic thought in general. For example, Empedocles' description of the porous membrane which surrounds the pupil of the eye, ${ }^{38}$ whose interstices are large enough to give passage to the particles of fire by which we see, but too small to let particles of water through, and his comparison of the whole structure to a lantern with its horn shutters, may fairly be called mechanistic. But it is doubtful whether we should want to characterize Empedocles' physical philosophy in general in this way, despite the extensive use which he makes of the concept of effluences and pores into which they fit. This is also true of the detailed explanations given by Anaxagoras or by Diogenes of Apollonia. They clearly tried to give naturalistic explanations, and they were resourceful in providing plausible detail. But they did not attempt tc reduce all explanations to one particular type. Some of their explanations are mechanistic in the sense that they have to do with solids and fluids, contacts and

\footnotetext{
${ }^{35}$ The Hippocratic surgical writers might well have been interested in such an application. They had a practical knowledge of apparatus using leverage and torsion for the reduction of dislocations, and a lively appreciation of their working ("Of all the apparatus contrived by men these three are the most powerful in action - the wheel and axle, the lever and the wedge" writes the author of Fractures (Jones 3, 172-3)); they must also have been conscious of the forces involved in muscular movement in the human subject. See for example the discussion of the posture adopted by an archer in Fractures 2 (Jones 3, pp. 98 and 99).

${ }^{36}$ Heronis Alexandrini opera, ed. Wilhelm Schmidt, vol. I, Leipzig, Teubner, 1899, p. 340, 13-18. These are painted figures, presumably with separate free-moving arms; the mechanism is described in XIV, 2-6, pp. 424-427. While the movements of the figures themselves are simple, and no doubt not particularly lifelike, the whole theatre was a relatively complex piece of machinery, allowing for a number of different movement-series or programmes. The mechanism was of strings and drums and weights, and the source of power was gravity, not pneumatic or hydraulic. See also A. G. Drachmann, The mechanical technology of Greek and Roman antiquity, Copenhagen, Munksgaard, 1963, p. 197.

${ }^{37}$ e.g. MRS, Proleg., cap. III, §v; tom. II, Proleg., cap. I, §xiii.

38 Fragment 84.
} 
pressures, and displacements, and some are not. But then we come to Democritus: and his example reminds us that there is a kind of mechanism in Greek philosophy which does show a thoroughgoing, exclusive, reductionist spirit. In Greek atomism, all the characteristics of things, and all natural processes, are reduced to the size, shape, and arrangement of the elementary particles and their mutual impact and pressure. Now one of the factors to which Greek atomism - including the Epicurean version - owed its success was the wide range of phenomena to which it could be applied, and applied in detail. It was not just that the atomists attempted to explain more things than their predecessors. It was also that they were able to take existing explanations and reduce them even further to atomistic terms by exploiting the latent corpuscular mechanism. ${ }^{39}$ Atomism was the logical conclusion of the direction taken by Greek philosophy after Parmenides, and the tendency towards a corpuscular theory of matter is already apparent in Empedocles. ${ }^{40}$

In the Hippocratic collection there is no mention of atomism, let alone any application of atomism to medicine. Most texts are probably too early to show such an influence. It is not until we come to the Hellenistic period - to Erasistratus ${ }^{41}$ (first half of third century B.C.) and later to Asclepiades of Bithynia (first century B.C.) - that we can be sure of identifying a systematic application of corpuscular physics, along with explicitly mechanistic modes of explanation, to physiology and pathology. By that time, mechanism, through debates in the philosophical schools, had become a fully self-conscious approach to physical questions, clearly defined by its opposition to other kinds of approach. ${ }^{42}$ There is, however, one group of Hippocratic texts which is more or less clearly differentiated from the rest by the detail into which it pursues physical explanations, and the consistent way in which it attempts to explain physiological and pathological processes in terms of the contact and pressure between

${ }^{39}$ Cf. W. K. C. Guthrie, A history of Greek philosophy, Cambridge University Press, 1965, vol. 2, pp. 470-471; ibid., pp. 373 and 426 on Democritus' theory of magnetism; pp. 465-466 on his account of the growth of horn in animals. Guthrie comments upon the painstaking detail of this account and its hint of Democritus' atomic theory. In both respects - which are typical of his method of explanation in minor matters - it is interesting to contrast this with Empedocles' description of the growth of nails (31 A78, in H. Diels and W. Kranz, Die Fragmente der Vorsokratiker, 6th ed., 3 vols., Berlin, 1951-52) as extensions of the tendons (neura) which grow hard when they encounter the chill of the outside air. See also Nature of the child, chap. 19 and 20 (R. Joly (editor), Hippocrate de la génération, Paris, Les Belles Lettres, 1970, pp. 64-66); G. E. R. Lloyd (editor), Hippocratic writings, Harmondsworth, Middx., Penguin Books, 1978, pp. 331-333.

${ }^{\circ}$ As noted by Aristotle (De generatione et corruptione, $325 \mathrm{~b} 5 \mathrm{ff}$.). See, in general, Guthrie, op. cit., note 39 above, pp. 147-152; and most recently James Longrigg, Isis, 1976, 67: esp. pp. 436-438. What Longrigg says about the application to physiology of Empedocles' theory of pores is particularly interesting in this respect. Pores and particles were to become a feature of corpuscular systems of physiology, both in antiquity (Asclepiades) and in the seventeenth and eighteenth centuries.

"For his debt to the physical philosophy of Strato of Lampsacus, see James Longrigg, Dictionary of scientific biography, New York, Scribner, 1971, vol. 4, 'Erasistratus', where earlier works are cited.

${ }^{22}$ What it entailed was expressed very clearly by Strato of Lampsacus (F. Wehrli, Straton von Lampsakos, Basle, Schwabe, 1950, Fr. 32): "Strato ... disclaims making any use of the services of the gods in constructing the world. Everything that is, he says, is effected by Nature ... everything that is or has come to be in the cosmos is brought about by natural weights and motions." The Stratonian concept of nature is used in Cicero's dialogue De natura deorum (3.27-28) as an alternative to animistic explanations by a conscious and intelligent nature. This may well represent the intention of Strato, whose teacher Theophrastus had objected to the covert animism in Aristotle's theory of the unmoved mover. 


\section{Hippocrates the iatromechanist}

solids and fluids, and the quantitative displacement between fluids. This is the group consisting of Seed, Nature of the child, and Diseases $4,{ }^{43}$ all certainly by the same author, and probably composed as one continuous treatise or lecture course. It gives an account of conception and genetics, embryology, a humoral theory of nutrition and digestion on which a general account of health and disease is based. Wellmann ${ }^{44}$ believed that the text was written by a pupil of Democritus, and identified many Democritean elements in it: some at least of his conclusions seem to be well founded. The doctrines of the text are not in themselves atomistic, although a case can be made for crediting several of them with an implicit form of atomism. What is significant is the way in which each of the processes with which the author has to deal is explained in mechanical and quantitative terms: for example, congenital defects in the child by the pressure of the womb on the growing foetus, or by a shortfall in the quantity of nutriment which it receives from the mother; ${ }^{45}$ the formation of milk by the exudation of part of the menstrual blood into the omentum by the pressure of the womb; ${ }^{46}$ there is also an elaborate analysis of the quantitative relation between the size of the growing embryo, the quantity of menstrual blood which it absorbs as nutriment, and the quantity which is discharged as the lochia; ${ }^{47}$ the occurrence of critical days in fever is related to a carefully worked out three-day cycle of ingestion, absorption, and evacuation of the nutrient humours. ${ }^{48}$ Two examples are particularly clear. The first is in Nature of the child 17 (VII 496-8 Li.) where the author explains how the embryo grows. Nutrient material in the form of blood ultimately derived from all parts of the mother's body passes through the umbilical cord. It is attracted (and its quantity governed) by the embryo's respiration which also sorts out the different ingredients in the nutrient material and impels them to their appropriate places. The way in which the author expresses this is by saying that like parts go to join their like; but the way in which he illustrates this venerable and animistic principle is by a mechanical model.

\footnotetext{
Suppose you were to tie a bladder on to the end of a pipe, and insert through the pipe earth, sand, and fine filings of lead. Now pour in water and blow through the pipe. First of all the ingredients will be thoroughly mixed up with the water, but after you have blown for a time, the lead will move toward the lead, the sand toward the sand, and the earth toward the earth. Now allow the ingredients to dry out and examine them by cutting around the bladder: you will find that like ingredients have gone to join like. Now the seed or rather the flesh is separated into members by precisely the same process, with like going to join like.
}

Democritus, too, had referred to the principle of like attraction (in a different connexion) and had illustrated it by the way in which grains of different size and shape, or pebbles on a beach, are sorted into classes by the movement of a sieve or the waves. ${ }^{49}$ This passage suggests a deliberate attempt to give a mechanistic motive cause for a

${ }^{43}$ VII, 470-614 Li; Joly (ed.), op. cit., note 39 above; an English translation, excluding Diseases 4, is available in Lloyd (ed.), op. cit., note 39 above, pp. 317-346.

44 'Spuren Demokrits von Abdera im Corpus Hippocraticum', Archeion, 1929, 1: 297-330.

45 Nature of the child chaps. 9-11.

46 Ibid., ch. 21.

47 Ibid., ch. 18.

4 Diseases 4 ch. 47 with chaps. 42-44.

49 Democritus Fragment 164. 
principle which was essentially animistic. Such a motive cause is also provided in the Hippocratic passage, where the movement imparted by the breath is an essential element in the sorting process. ${ }^{30}$

My second example is Disease 4.39. The four humours (here blood, bile, phlegm, and water) are each associated with a particular organ (heart, gall-bladder, head, and spleen). These act as reservoirs for the storage of the humours and their replenishment to any part of the body which lacks them, since health depends upon their quantitative equilibrium in the body. The humours are themselves replenished by the presence of these substances in food and drink. Since some kinds of food will contain more of a particular substance and some less, there is a need for reservoirs in the body to preserve a healthy balance. Appetite for a particular kind of food is explained by the lack of a particular humour. This whole system is illustrated by a demonstration model consisting of a number of bronze vessels interconnected by pipes.

\begin{abstract}
The case is similar to what it would be if one were to pour water into three or more bronze cauldrons, having first set them together on a perfectly level surface and having joined them together as neatly as possible by fitting pipes into drilled holes; and if one were then to pour water slowly into one of the vessels until all were filled by the water. For the water will flow from the first into the others until they are filled. Then, when they are full, if you draw off the water from one, the water will flow back in turn from the other vessels into this one, and the vessels will empty again in the same way as they received the water. Now it is the same with the body: when food and drink enter the stomach the body draws them off from the stomach and is filled along with its reservoirs. When on the other hand the stomach is emptied, the fluid is returned, in the same way as the first bronze cauldron received back water from the others. ${ }^{31}$
\end{abstract}

As in the previous example, a mechanical version is given of a process or state which is elsewhere expressed qualitatively. Here the traditional equilibrium or "isonomy" of opposites or humours, is explained by a crude kind of fluid mechanics. What makes this group of texts different from others in the Hippocratic collection is that such mechanically conceived explanations occur throughout, and their use is more than occasional. ${ }^{52}$

Summing up, we can say that causal explanations with mechanistic features are relatively common in Hippocratic texts and exist alongside others which are not in any convincing sense mechanistic. There is, however, one group of texts in which there is, perhaps, a deliberate attempt to reduce all explanations to the contact and pressure

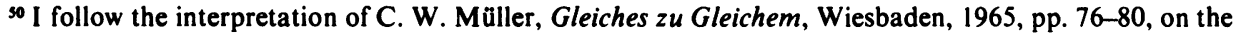
Democritean passage and pp. 115-118 on the Hippocratic passage.

31 VII, 556, 17-558, 6 Li; p. 92, 15-93, 3 Joly.

32 The author shows a marked tendency, reminiscent of Democritus, to articulate traditional explanations into greater detail than they had previously been given. For example, in several Hippocratic texts disease is explained by the secretion of some substance, an "opposite" or a humour, which when no longer blended with the rest, "dominates" them (epikratei) (cf. most explicitly Ancient medicine xiv, Jones 1, 38-39: the idea appears to originate in Alcmaeon (Fragment 4)). The author of Diseases 4 also adopts this theory; but he tries to explain how the separation occurs. He compares the whole process to the churning of butter: the humours become separated by a similar churning process in the body, in which the lightest humour, which is bile, rises to the surface while the heaviest, water, sinks to the bottom. (ch. 51, 108, 8-109, 1 Joly). That this analogy is meant as an explanation is shown by the author's remark that the effect of agitating a composite fluid is to cause pockets of empty space, into which a particular humour can move, and thus become separated from the others $(108,23-25 ; 109,10-14$ Joly). That the author is systematically applying a general physical principle about the relation between void and movement is clear from two further examples of the same principle (ch. 51, 110, 16-28 and ch. 57, 123, 7-26 Joly).
} 


\section{Hippocrates the iatromechanist}

between solid and fluid bodies. Both within and outside this group of texts there are passages of explanation which bear a strong family resemblance to the descriptions of physiological and pathological processes favoured by Hoffmann and other iatromechanists.

We must, therefore, be cautious in applying the word mechanism to Hippocratic medicine, and indeed to Greek philosophy in general before the time of Strato of Lampsacus. ${ }^{33}$ With the possible exception of Democritus, and of those texts which may have been influenced by him, mechanism in Hippocratic medicine and preSocratic philosophy was ante litteram and unconscious. Herein lies one great difference between the Hippocratic writers and Hoffmann. By mechanical medicine Hoffmann and his followers meant, at least as a desirable goal, the application of the principles of the science of mechanics to medicine, and his understanding of mechanism is derived from such an application. But this application was beyond the awareness of the Hippocratic medical writers. On the other hand, since on Hoffmann's own admission the application of mechanics to medicine was only a pious hope, the account which he gives of physiological and pathological processes is not precisely formulated in mathematical terms but is discursive and general. It might be described as a narrative of events mechanistically conceived. And herein lies the resemblance between his mechanism and the mechanism of the Hippocratic writers. In both processes, events are described in terms of the motion and impact of solid and fluid bodies. In neither is this description mathematical, nor are the motions and impacts expressed as instances of a set of laws. Hence the family resemblance referred to above between Hoffmann's explanations and those of the Hippocratic writers.

Ultimately, however, what engaged Hoffmann's interest in Hippocrates' "physical" writings may have been something rather different from the aspects of mechanism which I have examined so far. This is mechanism in the sense of a disposition to see natural processes in terms of the relations of balance and displacement between commensurable quantities.

But before examining this aspect of the Hippocratic writings, it will be helpful if we look first in some detail at the way in which Hoffmann presents Hippocrates, since it is that which determines his awareness of features in the Hippocratic view of human nature which seemed gratifyingly to confirm his own philosophical predilections.

\section{THE HOFFMANNIAN HIPPOCRATES}

Hoffmann does not argue from detailed examination of the texts to specifically mechanistic tendencies in Hippocrates. This is not to say that he was unaware of them, but in the event his strategy is somewhat different. Rather than substitute an entirely new model of Hippocrates, he takes a traditional one and represents it, by rhetorical assertion rather than by detailed argument, as mechanistic. Specifically, he does this by assuming that the concept of nature is central to Hippocratic "philosophy", and claiming that by nature Hippocrates intended precisely the same thing as he himself. ${ }^{34}$

\footnotetext{
${ }^{33}$ See note 42 above.

s4 Daniel Le Clerc, in his assessment of Hippocrates' "philosophy", gives a similar centrality to Hippocrates' concept of nature. After mentioning differences in doctrine between individual texts, he
} 


\section{Iain M. Lonie}

Hoffmann states or implies what he means by nature in a number of places in the MRS. Inspired as he was by the science of mechanics, the study of matter in motion, he begins from the concept of motion itself, which is inherent in matter, and has no exterior, "metaphysical" cause. The particular kind of motion with which the medical scientist is concerned is the motion of life, which Hoffmann defines in the preface addressed "ad solidioris doctrinae et peritiae medicos". It is "the circulatory motion of the blood and the humours, taking its departure from the systole and diastole of the heart, the arteries, and channels and fibres of every kind, which systole and diastole are maintained by the influx of the blood and the nervous fluid, and preserving the body from all corruption by secretions and excretions, and governing all its functions. This circulation is that vital motion which defends the blood, in itself highly prone to putrescence, from immediate corruption." the blood is itself that very Nature, the healer of diseases, whose praises the Ancients . never tired of singing."'s6

This reinterpretation of the nature of the Ancients was in itself an obvious and commonplace procedure, ${ }^{57}$ and it was also convenient for the practical aspect of medicine which Hoffmann wished to emphasize. It enabled him to tie together the old and the new, the traditional structure and content of practical medicine with the explanations inspired by the new philosophy. The extent to which the content of Hippocratic medicine could be retained by this manoeuvre may be seen from an inspection of the mechanistic commentaries on the Aphorisms which were popular in the eighteenth century. ${ }^{38}$

Hoffmann saw medicine as a unity, in which the three parts into which it had been divided - physiology, pathology, and therapy - were different expressions of one underlying concept: the "mechanism", or the vital motions, of the human body. Physiology explained the causes and effects, pathology examined them when they were disturbed, and therapy restored them to their natural and healthy state (MRS, tom. III, sect. I, cap. I; cf. tom. II, sect. I, cap. II, §iii). But the ultimate aim was practical, to treat and to cure the patient of his disease. The rational basis of medicine was an understanding of the vital machinery in sickness and health. But the other pillar upon which successful treatment rested was practical clinical experience, the habit of meticulous and detailed observation and careful recording through the whole course of a disease (tom. III, sect. I, cap. II; tom. II, Proleg., cap. I, §iv). ${ }^{99}$ Hoffmann

remarks that far more significant than such contradictions is the fact that throughout Hippocrates recognizes one overriding principle, and that is nature (Histoire de la médecine, Amsterdam, Aux dépens de la Compagnie, 1723, prem. part. liv. III, ch. II, p. 115).

${ }^{\text {ss }} \mathrm{Cf}$. also MRS, tom. II, cap. III, § ii.

s6 Cf. also MRS, tom. I, sect. I, cap. IX, §xxix, and De motuum febrilium indole ac sede (1723) §xxiii (suppl. 2, Pars 2, p. 16).

s7 It was a commonplace of the period: see Max Neuburger, Die Lehre von der Heilkraft der Natur, Stuttgart, Enke, 1926, p. 47. It might also be regarded as a virtually automatic consequence of substituting the circulation for the concept of innate heat, which Galen in some passages appeared to have identified with the nature of Hippocrates (see note 65 below).

st See above, p. 119 and note 14.

59 This is Hoffmann's own formulation of the venerable topic "experience and reason". There are, he says, two foundations of true pathology: "unum, plenissima omnium et singulorum morborum historia, quae ex compluribus observatis et annotatis circumstantiis nascitur: alterum est exquisitior corporis nostri 


\section{Hippocrates the iatromechanist}

had the reputation of being an excellent clinician himself, and he was careful to give detailed instructions for clinical observation and note-taking (tom. II, Proleg., cap. I, $\S \S$ ii-xi; cf. tom. III, sect. I, cap. II).

Clinical observation is traditionally associated with Hippocrates. The Roman Varro had long ago called him the founder of clinical medicine, ${ }^{60}$ and the usual attitude taken to him in this can be summed up as follows. The Epidemics are masterpieces of acute observation and succinct description, and their accuracy guarantees the trustworthiness of the Aphorisms and the prognostic works based upon them. You may believe Hippocrates with complete confidence, for his masterly practice of observation enabled him to see, and his unique style to depict faithfully, nature as she is. ${ }^{61}$

Hoffmann's attitude to Hippocrates in this is distinctly cool. "The infinite number of rules about the prognosis of diseases which are to be found in the writings of Hippocrates and the other Ancients are for the most part fallacious." The reason for this is their inadequate methods of observation: "these rules were drawn not from complete case histories of diseases, but from the fragments of these only, and from partial circumstances, not from every single circumstance." (Tom. III, sect. I, cap. II; cf. tom. II, cap. I, §xi). ${ }^{62}$ Although, then, it is as a practical physician that Hoffmann admires Hippocrates, this practical value did not lie, as it did for others, in the Aphorisms and prognostic texts, but in the "physical" works. This judgement perfectly accords with Hoffmann's aim: to found a better practical medicine upon the science of mechanics.

His judgement of Hippocrates is expressed most clearly in a passage introductory to the therapeutic volume of the MRS (tom. III, sect. I, cap. IV). The titles indicate the context: the title of the whole section is 'The foundation of rational therapy', while

\footnotetext{
structurae motuum omniumque earum rerum, quae illius statum mutare possunt, scientia." (Ibid.)

co Pliny, Natural history xxix, 2, ed. and trans. by W. H. S. Jones, London, Loeb Classical Library, 1951.

${ }^{61}$ Aphorisms are like steel mirrors which, when they have undergone the frequent polishing of experience, return to us the correct methodus medendi in accordance with the true reflection of nature (Giorgio Baglivi, De praxi medica, lib. I, cap. ix, op. cit., note 12 above, p. 75). The chapter is inspired by Bacon and is on the "obstacle" to medical progress which arises through discontinuing the practice of treating diseases "aphoristically". The notion that correct description of a disease will yield you the right way of treating it is, of course, Sydenhamian. For this functional approach to Hippocrates' style see John Freind, Hippocrates de morbis popularibus liber primus et tertius, 2nd ed., London, Gul. Innys, 1717, Preface to Richard Frewin. On the relation between Hippocrates' Epidemics and the prognostic aphorisms, see Henry Cope, Demonstratio medico-practica prognosticorum Hippocratis ea conferendo cum aegrotorum historiis in libro primo et tertio epidemiorum descriptis, Dublin, J. Smith \& G. Bruce, 1730. As the title indicates, Cope undertook to demonstrate the truth of Hippocratic prognosis by showing in detail that it was based upon the observations in Epidemics 1 and 3. The apparent petitio principii involved in this undertaking is an index of the way in which Hippocrates' observations were regarded as holy writ, particularly since Cope defends himself against the criticism of not using his own case histories with the plea that he might then be suspected of having cooked them. The same respect is expressed by van Swieten (op. cit., note 12 above, vol. 2, p. 606, on aphorism 779): the coincidence of the Prognostics and Aphorisms with the Epidemics supports the conclusion that Hippocrates' practical rules really are based on observation. Hence it is important to decide whether a particular aphorism is genuine or not (e.g. on §753, concerning Aphorisms 8.5. Ibid., vol. 2, p. 521).

${ }^{62} \mathrm{Hoffmann}$ 's attitude here is precisely opposed to that of Boerhaave: Prael. ac., op. cit., note 27 above, $\$ 871$, note 1: it was by his cultivation of semeiotics that Hippocrates earned the title of "divine". Cf. ibid., $\S 921$, note 1 .
} 
the chapter is 'The genealogy of diseases from disturbance in the mechanism of solids and fluids'. Many are the hypotheses which have been proposed in medicine, says Hoffmann, but none is more true than that proposed by Hippocrates. For he did not base his reasoning upon the qualities of matter, and empty names, but upon "the proportion, measure, temperament of the motions as much as of the humours of our body.... He made it his earnest endeavour to apply solid reasonings in a pure, mechanistic fashion with skill and understanding to the explanation of the difficult problems of medicine." ${ }^{63}$ He was the first, Hoffmann continues, to state that the body consists of solids, fluids, and the spirits which cause motion; ${ }^{64}$ and he was the first to make clear mention of the circulation of the blood. Would that Galen and his school had followed Hippocrates, instead of borrowing sterile ratiocinations from Aristotelian philosophy! But modern physicians, with their hypotheses conflated from Cartesian philosophy, chemistry, and the metaphysics of the schools, are no better. Hoffmann, however, would devote himself to the task of confirming the mechanical medicine which Hippocrates was the first to establish. (This remark suggests that Hoffmann really did see himself as the heir to Hippocrates: Hippocrates by tradition was the founder of rational medicine, which Hoffmann was to refound in his own time.)

What then is the true first principle which we should adopt in medicine? Hoffmann's answer is: Nature, as Hippocrates understood it, and as Hoffmann himself defines it, namely, the perennial progressive and circular motion of the blood and the humours through the vessels of the body, a motion impelled by the solids, and the motion of the solids themselves, which is impelled by the fluids (tom. III, sect. I, cap. IV, §§ii-vii).

It was traditional to see the Hippocratic concept of nature as a unifying principle behind his practical medicine, even though the unique value of that medicine lay in its many detailed observations. In the Galenic systematization of Hippocrates, diseases are caused by a distemper of the humours, and their natural course is towards recovery through the "concoction" of these humours by the innate heat ${ }^{65}$ and their elimination by the expulsive faculty. But these are only the chief instruments through which nature works, and it is nature herself who cures diseases. Good therapy is therefore based, in part, upon an understanding of this process, so that the physician can anticipate its events and know when to be ready to assist Nature. ${ }^{66}$

Hoffmann's own formulation of pathological processes differs somewhat from this,

${ }^{63}$ Cf. also MRS, tom. II, Proleg., cap. I, §̧xiii.

ot See below, p. 143 and note 92.

's Galen commonly identifies Hippocrates' nature with the temperate mixture of the four elements or the four qualities, which is a static rather than a dynamic conception (XV, $570 \mathrm{~K} . ; 1,675 \mathrm{~K}$;; XVII/2). But he identifies it with innate heat in several passages of his commentary upon the Aphorisms $(421 ; 716 ; 809 \mathrm{~K}$.; cf. also V.702; XVII/1, $599 \mathrm{~K}$.). The identification appears in a number of writers in the sixteenth century, most influentially perhaps in J. F. Fernel (Universa medicina, physiologia, Paris, A. Wechel, 1554, lib. IV, caps. vi and vii; cf. Therapeutice, lib. II, cap. ix). A. Foes (Oeconomia Hippocratis, Frankfurt, heirs of A. Wechel, 1588, s.v. $\varphi 6 \sigma i \zeta)$ gives both interpretations, as krasis of the elements and as innate heat, referring for the latter to Aphorisms i.15 and 5.22 (Jones 1.104-107 and 162-163).

${ }^{66}$ See Galen's commentary on Epidemics VI, 5, 1: "Natures are the physicians of diseases" (CMG V, 10, 2,2 , pp. 253-259, especially $254,28-255,3$ : "nature is the first to cure diseases, above all when she restores the man to health by evacuating the troublesome humours through a copious effusion of sweat or in the urine or by vomiting."). 


\section{Hippocrates the iatromechanist}

although it is certainly not in conflict with it. (The coction/crisis doctrine continued to function in medicine at least until the end of the eighteenth century; and it appears in Hoffmann, for example in the movement from centre to periphery which terminates fever. $)^{67}$ The substitution of innate heat by the circulation in the role of nature's chief instrument or nature herself was, historically, a virtually inevitable consequence of Harvey's discovery, ${ }^{68}$ and Hoffmann was not alone in making it. But by reinterpreting Hippocratic "nature" as the circulation of the blood and humours and the interaction of solids and fluids, Hoffmann was able to identify his own approach to medicine with that of Hippocrates. It was quite in accord with tradition that he should do this in the area of practical medicine. It also suited his own needs, since the justification of "rational", or mechanical, medicine must lie in its practical value.

Gestures of respect towards Hippocrates are common in the medical literature of the seventeenth and eighteenth centuries, and it is often difficult to decide their value. Hoffmann is eager to give his medicine a fine classical façade, like the builder of a Palladian villa. Yet his references to Hippocrates are not purely ornamental: they are too systematic for that, and they point to a serious motive, whose nature I have tried to indicate. He may, however, have felt that something more was needed to lend plausibility to the identification of his own system of medicine with that of Hippocrates. At any rate, he offered a reasoned and detailed argument of his position in the form of a dissertation presented in 1719.

\section{THE 'DE MEDICINA HIPPOCRATIS MECHANICA' (1719)69}

The announced intention of this dissertation is to inquire "how much the mechanical rational medicine of recent writers owes to Hippocrates, and how much of it was known to him in his own time".

Its plan is straightforward. Sections I-VII define and defend Hoffmann's general concept of mechanical medicine; the rest demonstrates in detail that this concept can be found in various Hippocratic texts. Sections X-XVII deal with physiology; XVIII-XXV with pathology and the factors which cause disease or maintain health; XXVI-XXVIII with therapy. Thus the dissertation follows the pattern of Hoffmann's major work. And indeed, quite apart from its professed purpose, it is a very clear and readable compendium of Hoffmann's main ideas.

\footnotetext{
${ }^{67}$ For Hoffmann's views on fever, see below pp. 146-147 and note 108. Hoffmann offers a mechanistic interpretation of the regular occurrence of crises in De crisium natura eiusque explanatione rationali (Opera, vol. 6, 173-181). Similarly, in De generatione febrium (suppl. 2, pars 2, 1-9) the idea of concoction is not rejected, but referred to as an "ancient mode of speaking" to describe the beneficial effects of fever upon the blood.

"s It was of course aided by the fact that Hippocrates, according to Galen, regarded the heart as the source of innate heat (V, $582 \mathrm{~K}$.). See also pseudo-Galen on Hippocrates, De alimento (a renaissance forgery, but widely read at the time) XV, $361-363 \mathrm{~K}$. This is a comment on the Hippocratic passage Nutriment 24 "The great source reaches to the outermost part; and from the outermost part reaches to the great source." The comment identifies this with the heart, the source of innate heat, which is in turn identified with nature. This became a key passage in the case for Hippocratic knowledge of the circulation, and the younger Riolan quotes it to this effect, along with the comment (Joannis Riolani ... Tractatus de motu sanguinis euisque circulatione vera, ex doctrina Hippocratis, in Opuscula anatomica, Paris, C. Meturas, 1652, 39-90.

69 Suppl. 2, pars 1, 110-120.
} 
Hoffmann begins with a definition of mechanical medicine:

\begin{abstract}
We define mechanics as the science of motions, which teaches the nature, causes and laws of these motions and their application to various uses. By mechanical medicine we mean that science which deduces all the effects which occur in the artistic construction of the human body, in respect of life, death and the cure of diseases, from corporeal causes and their various movements and dispositions to movement. Hence the mechanical medicine of today belongs par excellence to those whose allegiance is to the experimental philosophy and not to speculative philosophy: neither that which, not content with demonstrating the phenomena of the human body by mechanical explanations, has decided that a certain rational principle presides over the vital motions; nor that philosophy of the ancients who directed their attention more to the qualities of matter in explaining the causes of disease than to its motion. It is that motion which the mechanistic medicine of today examines more closely. Hence he is said to be a mechanical philosopher, who shows plainly how the effects of things follow from their structure by the power of the laws of motion. ... ( $(I$, p. 111.)
\end{abstract}

Hoffmann seems carefully to avoid stating that the laws of mechanics as such can be, or have been, successfully applied in medicine, but he certainly suggests that such an application is desirable. In the next section he says more on this point. He admits that medical concepts cannot be given a rigorous geometric demonstration, and he expressly disclaims any intention of attempting to do so. But the reason is purely the lack of sufficient data about the geometric structure and properties of the human body. The thing is not in itself impossible.

Evidently then mechanical medicine is to be used in this loose sense, a sense which made its identification in some Hippocratic texts easier.

There now follows a passage ( $\S \S I I I-V I I)$ which goes to some trouble to clarify the sense in which the body may be called a machine, and to describe its motive principle or principles. The passage is essential to our understanding of Hoffmann's concept of mechanism and his identification of it in Hippocrates. This machine "is a body constructed from various parts, mutually united by the great genius of the Artificer, with the purpose that it may produce definite and ordered movements." ( $\$ I I I$, quoted from MRS, I, 1, §ix.)

The actions of this body are accomplished by "innate motive forces" (viribus motricibus . . innatis). But what is the ultimate source of this motion? This is an obscure matter, much debated by the philosophers. Some, like the Stoics and Spinoza, identify it with God, and God with the world itself, which is permeated by mind. But Plato and the Platonists, Henry More for example, show a greater piety when they describe this universal spirit in material bodies as God's vicar. When we come to the source of the specific actions of the human body itself, some have described this as nature, soul, innate heat, or archeus. More correct however is Boyle's philosophy: Boyle in his Treatise on nature calls the nature of each individual body its mechanism, as being the principle and cause of every change in it:

Not without reason: for God, the highest arbiter, has produced active substances, or substances endowed with active forces, to be the springs of operations and effects in other things; and hence I hold, along with the illustrious Leibniz, that not for a moment can we conceive material things without an active power, or inclination, of changing their place ... whence I consider that the cause of motion is in no way to be sought outside of matter. ( $\$ \mathrm{~V}$.)

This view is opposed to that of many recent thinkers, who hold that matter is inert. Hoffmann next compares the body's mechanism to clockwork, in which the move- 


\section{Hippocrates the iatromechanist}

ment is determined by the arrangement of the parts; but it is also contrasted, in its minute perfection of detail, to such man-made machines. It is because of the superiority of God's understanding to that of man, that "no artificial automaton can preserve itself from corruption, or by its own proper forces regenerate itself, a thing which daily experience testifies to occur in the machine of the human body" ( $\S \mathrm{VI})$. This leads to the question of how the soul governs the body. Both the "occasional causes" alleged by Descartes and the pre-established harmony proposed by Leibniz, are matters which concern metaphysics, and not medicine. So far as medicine is concerned,

we firmly assert that life, health, nutrition, secretion and excretion, the circulation of the blood and the humours, the involuntary motions of the muscles, and finally the cure of diseases, popularly ascribed to nature, along with other motions tending to health, depend in a purely mechanical way upon mechanical and physical causes, without any participation of the rational soul being necessary. (§VIII.)

The philosophical context in which the concept of nature and mechanism is placed in these passages, as well as the actual language used, closely correspond to the context and language of the dissertation De natura morborum medicatrice mechanica of 1699, (cf. p. 117 above). There Hoffmann had aligned himself with Leibniz, and we can read the same alignment from the present passage. Matter for Hoffmann, as for Leibniz, is not inert (the Cartesian view), but contains forces or "active substances", a Leibnizean phrase. This alignment will explain, as we shall see, why Hoffmann found it easy to identify his concept of nature with that which he found in some Hippocratic texts.

In section VIII Hoffmann turns to the question whether the claim that Hippocratic medicine is mechanical can be justified. Clearly all the discoveries of more recent times cannot be ascribed to him. But mechanical medicine is latent in his works: the seeds and the principles are there and, he somewhat revealingly says, "anyone imbued with the mechanical philosophy will not find it difficult to dig them out from his writings" ( $\S I X$, p. 114). That Hippocrates regarded the body as a machine, whose parts work in harmony, can be demonstrated from a number of passages. The author cites Places in man (=VI 278, 5-9 Li.): "if the smallest part of the body is injured, the whole body feels the effect: the reason is that in the smallest part is contained all that is in the greatest". Immediately after this he cites a passage from Regimen 1.6: "Men saw a log; the one pul's and the other pushes, but herein they do the same thing, and while making less they make more. Such is the nature of man. One part pushes, the other pulls; one part gives, the other takes. It gives to this and takes from that, and to one it gives so much the more, while that from which it takes is so much the less." (Trans. Jones.) On this passage he comments: "the author attempts to demonstrate the mechanism of the body by a likeness. . . . He expressly compares nature to mechanic craftsmen". This quotation, and the comment, might well have reminded the contemporary reader of a striking passage (also quoted by Boerhaave) in Giorgio Baglivi. I quote it in full, because it precisely illustrates the way in which all these references to machines and mechanisms were understood;

After physicians began to examine the structure and effects of the animate body in the light of geometrical and mechanical principles and by means of physical mechanical and chemical experiments, 


\section{Iain M. Lonie}

not only did they uncover countless facts unknown to earlier ages, but they recognized that in truth the human body, so far as its natural actions are concerned, is nothing other than a complex of chemical and mechanical motions, which nevertheless depend upon purely mathematical principles. For whoever attentively examines its structure, will indeed find in the jaws and teeth, a pair of shears; in the stomach, a phial; in the veins, arteries and other channels, water pipes; in the heart, a pump; in the viscera, a sieve or riddle; bellows in the thorax; the power of a lever in the muscles; pulleys at the corners of the eyes; and so on for the other parts. (Prax. med., lib. I, cap. VI, vii.)

Hoffmann also refers in this connexion to the passage on the shape and structure of organs in Ancient medicine 22, which I cited earlier (cf. p. 126 above).

The passage from Places in man cited above is also quoted in a conspicuous part of the MRS, the first chapter of the first section, where Hoffmann gives a clear indication of how he thought it should be read. Man is composed of mind, and body, which is the instrument of mind and is the proper subject of medicine. This body is a machine, for the primary characteristic of machines is that they are unions of parts which are designed to work together. We can see this in a simple machine such as a clock or a mill, and we can also see it in the body. Such is the cohesion of parts in a machine, that injury to any one part will affect the working of the whole. Hence Hippocrates was quite right to say, in Places in man, that "if the smallest part of the body is injured, the whole body feels the effect". In the rest of the chapter Hoffmann describes the hydraulic structure of the body, which is composed of vessels of incredible fineness, as recent anatomical research has shown. What preserves the body from dissolution is the motion of fluids through this structure, the source of this motion being the heart. This whole mechanism is none other than that which the Ancients honoured with the name of nature, attributing to it marvellous powers of preserving life and curing disease.

The passage from Places in man belongs to a group of similar passages in the Hippocratic corpus. It will be helpful to our understanding both of the nature and sources of Hoffmann's mechanism, and of a basic feature of Hippocratic medicine itself, if we look at some of them. One of the most familiar occurs at the beginning of Places in man, and in fact introduces the argument of which the passage just cited is a part: "The body has no beginning, but everything is beginning and end alike: for when a circle has been drawn, its beginning cannot be found."71 Another of these passages

\footnotetext{
7 Baglivi's immediate source was probably G. A. Borelli, De motu animalium, vol. I, Rome, A. Bernabo, 1680, Praefatio: “. . . animalium operationes fiunt a causis, et instrumentis, et rationibus mechanicis, nempe libra, vecte, trochlea, tympano, cuneo, coclea etc. . ..". See also the very similar passages in Boerhaave, Inst. med., op. cit., note 27 above, \$39, and in John Quincy's introduction to his translation of Sanctorius (Medicina statica: being the aphorisms of Sanctorius translated into English, 3rd ed., London, W. \& J. Newton, 1723, 36).

" This passage, from what was perhaps Hoffmann's favourite Hippocratic text, was often quoted in medical literature. Together with a similar passage in Nature of bones (IX, 182, 3-6 Li.), it was often cited in support of the claim that Hippocrates knew of the circulation. Richard Mead, however, quotes it specifically to illustrate the reciprocity of function in the body: God "was pleased that our body should be a fabric of that sort, by disposing all its powers in such a manner, that they should form a kind of circle... . Hence it manifestly appears, that the animal machine is made, not by parts, but all together.... For example, how can the heart contract, to push the blood forward, without the assistance of the animal spirits; or the spirits be secreted without the brain? . . . Therefore Hippocrates said very justly. .... [the quotation follows] (Richard Mead, Works, London, C. Hitch et al., 1762, pp. 458-489). Van Swieten, too, used it to illustrate the reciprocity of action between heart and cerebellum (op. cit., note 12 above, vol. I, p. 2). Such reciprocity was precisely what Hoffmann meant by mechanism.
} 


\section{Hippocrates the iatromechanist}

occurs in Regimen: "Basketmakers work in a circle, starting from the beginning and finishing at the beginning: in the body we find the same circular progression; whence it began, to that it comes in the end."'2 Kirk, Kahn, and Guthrie cite these passages in discussing the themes of circular motion and the soul in pre-Socratic philosophy, and this is certainly the most illuminating context in which they can be read. ${ }^{73} \mathrm{Kahn}$, discussing the statement attributed to the philosopher and physician Alcmaeon of Croton (c. 500 B.C.) that men die because "they cannot join the end to the beginning", comments, "In the human subject, which is of primary concern for a doctor like Alcmaeon, the maintenance of life depends upon the circular knitting-together of all parts into one continuous whole." 14 But for the Hippocratic writers the particular substrate of this circularity was the humoral theory and its associated vascular system. The passage from Places in man has also been quoted in a celebrated article by Temkin to illustrate the Hippocratic conception of man as a unity and the related view of disease as something which affects the whole individual. Temkin points out the intimate connexion of the humoral theory with this view; and he also explains the often highly speculative nature of Hippocratic vascular anatomy by the need to provide for free communication of the humours. ${ }^{75}$ Places in man does explicitly say that "all the veins are connected and flow into each other, some being connected with themselves, and others through the little veins (phlebia) which extend from the veins which nourish the flesh". (3. VI $28222-25 \mathrm{Li}$.) ${ }^{76}$ Since this passage occurs at the end of the description of veins, it is reasonable to take it as summing up the main feature and purpose of that description.

Bearing all these factors in mind, we can say that the humoral theory was the way in which Hippocratic writers gave expression - for quite practical purposes - to a conception of man as a unity which was probably assumed in common by the Greek philosophers. Behind this conception was another, deeply established in Greek thought, of life or soul as recurrent or circular movement. Against this background, the passage in Places in man has a nuance strongly opposed to the description of man

\footnotetext{
The idea survives, although the source is forgotten. The following is from the introduction to a modern textbook of physiology: "The bodily activities are so closely dependent on one another that the workings of one part of the system cannot be comprehended without an understanding of the functioning of the whole. For example, in describing the activities of the heart we have to discuss the influence of the peripheral blood vessels, of the central nervous system, of respiration and of the chemical changes occurring in cardiac muscle. Our subject may therefore be likened to a circle..." (George H. Bell, J. Norman Davidson, Harold Scarborough, Textbook of physiology and biochemistry, 7th ed., Edinburgh, Livingstone, 1968, p. 4). Not a word here that might not have appeared in Hoffmann. But the book itself would have been a puzzle and a wonder to him.

72 Jones 4.256.

${ }^{73}$ G. S. Kirk, Heraclitus: the cosmic fragments, Cambridge University Press, 1954, p. 114 (Kirk says "It is evident that the coincidence of beginning and end was a theme of especial interest to doctors; this was because one of the problems was to discover the arche of the body, so as to begin treatment there."); C. H. Kahn in Festschrift Ernst Kapp, Hamburg, von Schröder, 1958, pp. 19-29; C. H. Kahn, The art and thought of Heraclitus, Cambridge University Press, 1979; Guthrie, op. cit., note 39 above, vol. 1 (1962), pp. 350-357.

${ }^{74}$ Kahn, Festschrift op. cit., note 73 above, p. 26.

is O. Temkin, 'Der Systematische Zusammenhang im Corpus Hippocraticum', Kyklos, 1928, 1: 9-43.

${ }^{76}$ One of the passages commonly cited to support the case for Hippocratic circulation; by Hoffmann himself in MRS, tom. I, sect. I, cap. VI, §ii.
} 


\section{Iain M. Lonie}

as a machine or automaton. It points to a vitalist, not a mechanistic, view of man. What is latent in Places in man becomes quite explicit in another passage quoted in the same paragraph of the dissertation, and one which was even more celebrated in the history of medicine: "One flowing together, one breathing together, all things in sympathy. All parts in the whole, and the parts in each particular part, with a view to the function." (Nutriment 23, IX $106 \mathrm{Li}$.) This author was certainly not describing a machine, but an organic unity, a żon. For although this passage was regarded by Galen as expressing a peculiarly Hippocratic conception, the text on Nutriment was undoubtedly influenced by Stoicism; ${ }^{71}$ and this particular passage has clear affiliations with the Stoic doctrine of cosmic "sympathy"." According to this doctrine" all parts of, and all events in, the cosmos are associated with each other as in a living body, because the universe itself is a living, breathing whole, a vast zōon. The name which the Stoics gave to the principle which "binds together" (syndei) the animal and makes it one, was physis, nature, of which the physical aspect is pneuma, spirit.

The modern reader, for whom "mechanism" suggests something like the Cartesian model of man or that expressed in the passage from Baglivi quoted earlier, may feel that Hoffmann has performed a sleight of hand in calling such a view of nature mechanical. ${ }^{80}$ This feeling is justified to the extent that some of those writers whom Hoffmann brought together under the banner of mechanism would certainly not have accepted Hoffmann's view of nature, which is neither Cartesian nor Newtonian. Yet Hoffmann himself saw no contradiction between the idea of a machine and that of an organism. He did not do so. because of the Leibnizean concept of nature from which he started, and which is made explicit at the beginning of the dissertation. That Hoffmann aligned himself with Leibniz can now, at this stage in our argument, be confirmed if we look at certain passages in Leibniz. In the Monadology, published five years before the dissertation, in 1714, Leibniz quoted the same passage from Nutriment to illustrate the interconnexion of things in the Leibnizean universe.81 Admittedly, Leibniz is not, as Hoffmann is, writing of the human body, but he goes on to describe the body, which is a part of the whole, in the same terms. As with the universe, so with the human body: it is a machine in all its parts, and this is what differentiates divinely created from man-made machines.82 Thus Leibniz has no

"This is shown by H. Diller, 'Eine stoische-pneumatische Schrift im Corpus Hippocraticum', Sudhoffs Arch., 1936, 29: 178-195. (Kleine Schriften, Berlin, de Gruyter, 1973, pp. 17-30.)

${ }^{n}$ Cf. the very similar language in Cicero, De natura deorum 2.19, where this idea is expressed: "tanta rerum consentiens, conspirans, continuata cognatio" ("the kinship of the universe, feeling together, breathing together, joined together"); "omnibus inter se concinentibus mundi partibus" ("all parts of the universe united in harmony"); this is only possible because the whole is held together by one undivided spirit ("uno divino et continuato spiritu").

" See esp. K. Reinhardt, Kosmos und Sympathie, Munich, Beck, 1926.

" Cf. Lester S. King, The road to medical enlightenment, 1650-1695, London and New York, Macdonald, 1970, p. 191: "Hoffmann in essence took a sort of animistic view, but by verbal juggling called it mechanical." The juggling, if that is what it is, is due to Leibniz.

"Monadology (1714), \$61 (Leibniz, Philosophical writings, London, Everyman edition, 1934, p. 14). The same Hippocratic passage was also quoted by Leibniz in an unpublished fragment dated 1676: see L. Coutourat, Opuscules et fragments inédits de Leibniz, 1903, (reprint, Hildesheim, Olms, 1961), p. 14. In both passages it is used to underline the point that the universe is a plenum in which all events are interconnected.

${ }^{22}$ Monadology, $\S 64$, op. cit., note 81 above, p. 15. Cf. "New system of the nature and communication of substances as well as of the union existing between the soul and the body" (1695). Ibid., p. 103. 


\section{Hippocrates the iatromechanist}

objection - on the contrary - to uniting the concepts of organism and automaton in one sentence: "And this body is organic, when it forms a kind of automaton or natural machine, which is a machine not only as a whole but also in its smallest observable parts." ${ }^{83}$ It is precisely this "natural machine" which we find in Hoffmann - and which he found in Hippocrates. That he should have done so, sharpens our awareness of the extent to which just such an organic conception of human nature is inherent in Hippocratic thought. Equally, the fact that Hoffmann called it a mechanism sharpens our awareness of the disparity between the Hippocratic view of man and the mechanist view held by some thinkers in the seventeenth century. For all that, there are latent ambiguities in the Hippocratic view. In particular, the Hippocratic humoral/vascular theory tends to be used in the service of an organic view of man, yet there is nothing in the humoral theory as such which limits it to that use. We have seen that some explanations of physiological processes in Hippocratic texts are very similar in form to mechanist explanations of such processes in the seventeenth and eighteenth centuries. And in Diseases 4 the humoral/vascular theory seems to be used in the service of a type of explanation which shows a definite tendency to move away from the organic conception of man.

Up to this point the dissertation has been concerned to identify Hoffmann's concept of mechanism in Hippocrates in general terms. It now proceeds to establish this identification in detail. Hippocrates' comparison of the body to a circle can "easily" be understood in the quite specific sense of the reciprocal, clockwork-like oscillation between solids and fluids, which is transmitted in the semen at conception and which persists inertially: "Once the parts which are prolific of sperm have set going an elastic movement in the solid and fluid parts of the foetus, this elastic force (elater) perpetuates its effort in these parts, because of the equilibrium between fluids and solids and the perpetual collision of each with the other."

The two main components of this mechanism are the circulation of the blood and humours, and the alternate contraction and expansion of the solids. If, therefore, Hippocrates' medicine is mechanistic in Hoffmann's sense, he must have been aware of the circulation of the blood and the contraction of the fibrous parts. Hoffmann recognizes that this point is crucial. That Hippocrates was "entirely aware" (Hippocratem ... minime latuisse, ibid., XV) of the circulation can be easily dug out of his writings, which support the conclusion that the circulation was "not at all unknown" to him.

Hoffmann is more confident here than he is in the MRS, where he refers several times to this question. In the Prolegomena (cap. IV, §xii) he says that there are "traces" (vestigia) in Hippocrates of a knowledge of the circulation, and in the introduction to the general pathology, that Hippocrates had been the first to mention circulation (tom. III, sect. I, cap. IV, §iii). He adds "especially in the work on Breaths". Elsewhere his language is more qualified: "The great Hippocrates left traces and indications of the circulation in his works, but because the study of anatomy was not cultivated then, the matter could not be fully uncovered." (tom. I, sect. I, cap.

33 "Principles of nature and of grace, founded on reason" (1714), §3. Ibid., p. 22.

" De medicina Hippocratis mechanica, §XII. 
VI, §ii). He adds five quotations, from Regimen, Breaths, Nutriment, and Places in man.)

As Hoffmann says, the question had been much debated, notably by Riolan the younger, ${ }^{85}$ Walaeus, ${ }^{86}$ and in the elaborate research programme in which Van der Linden engaged his pupils. ${ }^{87}$ Hoffmann does not refer by name to those earlier discussions, evidently regarding the matter as settled.

It was not in itself absurd to maintain that Hippocrates had been "aware", in a general way, of some kind of continuous circulation of the blood and the humours given Hoffmann's qualification about Hippocratic ignorance of anatomy, which permitted him to excuse Hippocrates from knowing all the essential points of Harvey's discovery. Regimen does speak mysteriously of periodoi, evidently "circulations", in a number of passages, ${ }^{88}$ and in one of haimatos periodos, ${ }^{89}$ which at any rate looks like sanguinis circulatio; while Nutriment mentions a reciprocal movement of nutriment from the centre to the periphery and back again.90 Given the general ideological framework within which Hoffmann read Hippocrates, it would have been exceedingly tempting for him to interpret such passages in a quite specific way. He may therefore have regarded the point as sufficiently proven.

A demonstration that Hippocrates was aware of the circulation was clearly necessary for Hoffmann's case. Harvey's discovery had raised problems for the traditional acceptance of Hippocrates. The easiest solution was to hold that Hippocrates had been ignorant of the circulation but, so acute were his powers of observation, that he had accurately recorded those facts about health and disease for

\footnotetext{
${ }^{85}$ Riolan, op. cit., note 68 above. Riolan mustered all the Hippocratic passages to which subsequent writers refer in support of his own (and against Harvey's) theory of the circulation. There are three circulations, not one, which he professes to find in Hippocrates' book on Dreams (=Regimen 4, Jones 4, 420-447). Riolan's approach is a salutary reminder that it was not simply a question of whether the Harveian circulation could be found in Hippocrates. On Riolan, see N. Mani, 'Jean Riolan II (1580-1657) and medical research', Bull. Hist. Med., 1968, 42: 121-144, esp. p. 131.

* Johannis Walaei Epistolae duae de motu chyli et sanguinis ad Thomam Batholinum, printed in successive editions of Bartholin's Anatomia. The third (1645) and subsequent printings contain a passage which attributes genuine knowledge of the (Harveian) circulation to the Ancients, a knowledge which was obscured by later writers, because they did not understand that by "veins" earlier writers meant veins and arteries. Walaeus refers to the "three circuits of heat and moisture" in Regimen 1; Nature of bones (IX, 182, 3-6 Li.); Nature of man (xi, Jones 4, 33); and Nutriment where the theory is "more manifest", from which he cites three passages (ix, xxii, and xxiii, Jones 1, 344-345, 348-349, 350-351). (All these passages are mentioned by Hoffmann or by his pupil.) (Thomae Bartholini Anatome, 10th ed., Leiden, Off. Hackiana, [1674], pp. 773-774.) On this passage see W. Pagel, New light on William Harvey, Basle, Karger, 1976, pp. 120-121.

${ }^{87}$ Joannes Antonides van der Linden, Hippocratis de circuitu sanguinis exercitationes xxvii, Leiden, 1659, This study seems to have become the standard authority for those who accepted its conclusions, e.g. D. W. Triller, in Opuscula medica, vol. II, Frankfurt and Leipzig, Fleischer, 1766-1772, vol. 2, p. 218. On van der Linden's work see Robert Willis, William Harvey: a history of the discovery of the circulation of the blood, London, Kegan Paul, 1878, pp. 22, 323-324; G. Sarton, in E. Ashworth Underwood (editor), Science, medicine and history, London, Oxford University Press, 1953, vol. 2, pp. 14-15; and G. Preiser, 'Zur Hippokrates-auffassung des Johannes Antonides van der Linden', Med.-hist. J., 1969, 4: 305-313, esp. 310-311. Sarton had not inspected the work himself, and unfortunately relied upon Willis, whose citation from Hippocrates' Dreams is both misprinted and mistranslated, and makes van der Linden look more of a fool than he was.

e.g. xix, Jones 4, 256; Ixvi, 360; Ixxxix, 426.

9 xc, Jones 4, 438.

${ }^{90}$ xxii (Jones 1,349 ). See also xxiv (Jones 1,351 ) and note 68 above.
} 


\section{Hippocrates the iatromechanist}

which only now could a correct explanation be given. This, on the whole, was the solution adopted by Boerhaave. ${ }^{91}$ It might then be maintained that Hippocratic "nature" was in fact the circulation, though Hippocrates himself did not know it. But Hoffmann, who had set himself the more difficult task of demonstrating that Hippocratic medicine was governed by a mechanist physiology and pathology, could not take this way out of the difficulty.

But although the demonstration was necessary, it was not in itself sufficient. Hippocrates, as well as knowing of the circulation, must also have been a "solidist". He must at least have known of the "elastic power" of the fibres which accounted for the heart's motion and the impulsion of the fluids in general through the body. Otherwise the whole clockwork of the reciprocal action of solids upon fluids, fluids upon solids, and the inherence of the principle of motion in matter itself - the very essence of Hoffmann's mechanism - could not be attributed to him.

Hoffmann's own account of the way in which the principle of motion actually works is anything but clear and consistent. Since it is essential to his system, we must at least briefly examine it in order to find out what he is attributing to Hippocrates. A convenient place to begin is with a Hippocratic passage, which, along with Galen's gloss, was influential upon medicine from the medieval period on. A sentence in Epidemics 6 (V 346, 5-6 Li.) speaks of "the things which are contained, the things which contain, and the things which give impulse," which Galen interpreted as the fluids, the solids, and the spirits. ${ }^{92}$ These traditional elements are the elements of Hoffmann's system. In the early Fundamenta medicinae (1694) he describes the animal spirits "quasi impetum facientes" (FM I, iii, 5: impetum faciens was the usual translation of Hippocrates' and Galen's to enhormōn). The animal spirits, along with blood, serum, and lymph, make up the principal fluids. However, in FM I, vi, 2 Hoffmann says that the motion of both solids and fluids depends upon the "nervous fluid". This suggests an identification of animal spirits with nervous fluid which does in fact seem to be made in FM I, v, 44-55.93 However, in the MRS Hoffmann appears to have given up talking about animal spirits, and instead regularly uses the term nervous fluid (cf. tom. I, lib. I, sect. III passim).

This is said in a number of places to be the cause, or at least a contributory cause, of

\footnotetext{
${ }^{91}$ Prael. ac. op. cit., note 27 above, $\S 18$, n. 1; and esp. 1149, n. 1: "Though Hippocrates understood not the circulation of the blood, yet by accurately observing the effects of the disease, which he looked upon as an unknown entity, and by remarking the endeavours of nature, by which the disease tended to either health or recovery, did from thence deduce a proper method of cure ...; and thus Hippocrates, ignorant of the causes, cured diseases as well as ourselves, stocked with so many discoveries." Harvey himself had said that "the circulation of the blood does not shake, but much rather confirms the ancient medicine; though it runs counter to the physiology of physicians." (Works, Willis's trans., p. 91. Cf. O. Temkin, Galenism, Ithaca and London, Cornell University Press, 1973, p. 158, n. 57 where this passage is quoted.)

92 The part of Galen's commentary on Epidemics 6 where he discusses this passage survives only in Arabic. Galen's interpretation was probably most familiar through De febrium differentiis 1.2 (VII, $278 \mathrm{~K}$.) or from pseudo-Galen Introductio sive medicus (XIV, 696-7 K.) But it had already become a commonplace in the medieval period.

${ }^{93}$ For the physiology of Fundamenta medicinae and the role in it of "aether", see Rothschuh, op. cit., note 1 above, pp. 174-178. Aether is present in both the blood and the spirits, and is the ultimate cause of motion in them, the factor which animates them. It is not clear to me how far this conception survives in MRS, and Hoffmann's manner of dealing with such basic questions does not inspire much confidence that he had ever worked out, even for his own satisfaction, a clear and consistent doctrine on the matter.
} 


\section{Iain M. Lonie}

the systolic motion of the solid parts, and therefore of the motion of the fluids (tom. I, lib. I, sect. I, cap. VI, §xxv; lib. II, cap. I, §xi; tom. II, Proleg., cap. III, §x). This fluid is the cause of both voluntary and involuntary movement (tom. I, lib. I, sect. III, cap. II, §iv) and it is the instrument of the soul (ibid., cap. VII, §vii). However, it is not altogether distinct from blood, since it is derived from "the most spirituous and subtle part of the chyle, lymph, and blood" (ibid., cap. I, §v), or from arterial blood (ibid., cap. VII, §viii). More commonly, Hoffmann's language suggests that it exists alongside the blood, ${ }^{94}$ e.g. in the coronary arteries, where both fluids cause the contraction of the heart, which is dilated by the pressure of the blood itself (tom. I, lib. I, sect. I, cap. III, §xx).

The conception is very vague and imprecise, almost offhand. Nor is it made clear exactly how nervous fluid causes the heart to contract. ${ }^{95}$ But the chief omission is any clear explanation of how the nervous fluid itself is impelled through the system: Baglivi here was equally vague and contradictory. ${ }^{96}$ However, although the details are blurred and confused, the general conception is clear enough. Solids impel the fluids by systolic contraction, but the "elastic power" (elater) which enables them to do this is itself caused, or stimulated, partly or wholly, by the fluids, or by some of them, or by one of them. Thus as Hippocrates says, the whole process is like a circle in which you can find neither beginning nor end.

The elasticity of the fibres, and the action upon these of the nervous fluid, is therefore an essential ingredient of Hoffmann's mechanism. But it is precisely at this point that seventeenth-century physiology begins to diverge most widely from Hippocratic or Galenic physiology. The nervous fluid itself is the direct descendant of the Hippocratic air or pneuma, and of Galenic animal spirits. This is recognized by Hoffmann in his use of the term animal spirits and his identification of them with nervous fluid in the Fundamenta medicinae; and, in the dissertation ( $\$ x v i)$, in his equation of "the generation and function of the nervous fluid" with the distribution of air from the brain to the rest of the body in Sacred disease 19 (Jones 2, 178-9). But an interest in the structure and behaviour of the fibres was almost entirely the product of recent anatomical investigation. Hoffmann is therefore hard put to it to discover traces of this "solidism" in Hippocrates. True, Baglivi had claimed that his interest in the fibres had been prompted by the observation that Hippocratic treatment was

\footnotetext{
9RS, tom. I, sect. I, cap. III, § vi: "motus qui fiunt in partibus solidis corporis nostri a fluidis ipsoque sanguine calido et partibus eius subtilissimis, sive impetum facientibus, tam in vasis quam in nervis contentis, proficisci, multis evidentibus argumentis potest evinci." The "subtle parts which give impetus" are presumably the aether: see note 93.

95 For the explanation in Fundamenta medicinae, which is similarly terse, see Rothschuh, op. cit., note 1 above, p. 176.

* G. Baglivi, De fibra motrice cap. V, “De comparatione motus cordis et durae matris". The systolic contraction of the dura mater is autonomous, and is maintained by the equilibrium which is set up in the foetus (op. cit., note 12 above, p. 182). In the letter to Hecquet printed at the end of this chapter, Baglivi discusses further this innate motion, and compares it to inertial motion. However, in cap. VII he appears to regard the nervous fluid itself as imparting the initial motion, a very slight one, in any series of muscular movements: just as automata can move without the assistance of any fluid but, like clocks "solely because of the peculiar construction (compages) of their solid components", human fibres also may at the slightest impulse of a fluid acquire a motion which increases as it is propagated (p. 205). (Baglivi here uses the example of automata in precisely the same way as had Aristotle: see above, pp. 126-127).
} 


\section{Hippocrates the iatromechanist}

directed rather at diseases of the solids than at diseases of the humours, ${ }^{97}$ but this seems to be a distortion. Hoffmann could convincingly refer to only one relevant passage, taken from his favourite text Places in man. In MRS tom. I, lib. I, sect. I, cap. IV, §i, he remarks, "That elastic movement which we ascribe to the fibres of the solid parts, Hippocrates in Places in man calls the 'tension and astriction of the skin'." Further down he quotes the passage itself (9. VI 292, 1-6 Li.): "Fluxions caused by cold occur when the flesh and the veins in the head are tense. The flesh is chilled and contracts and squeezes, and the veins in consequence force out the fluid, while the flesh itself contracts and exerts an opposing pressure; and the hairs erect because they are squeezed on all sides." On this Hoffmann comments: "In these words Hippocrates clearly indicates that it is by tension, pressure, and astriction of the fibres that the humours are expelled from one place to another" (ibid., §xvi). He also refers to a passage in the fragment Diseases in young girls $(=$ Virg. VIII, 466, 20-468, $5 \mathrm{Li}$.) and to Aphorisms V, 50. The former recommends a footbath of cold water to drive the blood up the legs again when they are congested after long sitting; that the water causes contraction of the fibres is Baglivi's interpretation. ${ }^{98}$ The aphorism says, "If you wish to inhibit menstruation, apply to the breasts a cupping-glass of the largest size." Nothing is said about contraction of the fibres here, and it is hard to see why Hoffmann referred to it. On the other hand, there are passages in the Hippocratic collection which use the cupping-glass as an analogy to explain the movement of fluid from one part to another. This movement, however, is explained by the force of attraction, which is attributed to the fact either that the cupping-glass is hollow, or that it is heated.99

Here, quite inadvertently, Hoffmann has drawn attention to a difference between Hippocratic mechanism and his own. In the former, the source of movement is just as likely to be a force of attraction as one of impulsion, operating by direct contact. This attraction is either assumed as a basic fact (like attracts like), or explained on the principle of horror vacui. Although words like thlipsis ("squeezing") ${ }^{100}$ and ananke (of which the basic meaning seems to be "pressure") are common in those texts which offer mechanistic explanations, the movement of humours in the body is not systematically explained by pressure of the solid parts, as opposed to explanations by the attraction of likes, or by the attraction of void spaces. Often the movement of

\footnotetext{
${ }^{9}$ De fibra motrice, Praefatio, in Opera omnia, op. cit., note 12 above, p. 163: in his assiduous reading of Hippocrates, Baglivi had observed that almost all Hippocratic remedies are directed at the solids and not at the humours. This led him to suspect that Hippocrates held a secret doctrine about the solids, which he did not divulge to posterity. Hoffmann repeats his remark in MRS, tom. III, sect. I, cap. IV, § xlvi.

* Baglivi - as often - is Hoffmann's source here, since it is only his interpretation which makes the reference intelligible. He quotes the passage and comments: "Huius mechanices(!) optime conscius divinus senex quandam torporis speciem a longo insessu productam . . . frigida lotione celerrime curat." (De fibra motrice cap. VIII, Opera omnia, op. cit., note 12 above, p. 210) Hoffmann's debt to Baglivi appears very clearly in the latter's comment at the end of the chapter: "Strictum et laxum in fluidis aeque ac solidis viget et morborum vera causa est ..." (ibid., p. 212).

9 See note 31 above. The explanation of the mechanics of the cupping-glass is implicit in the passages mentioned there. Aristotle seems to have regarded heat as the cause of attraction (Generation of animals $2.4,739 \mathrm{~b} 9$ ) and Strato of Lampsacus gave an explanation in which he correctly combined the two factors of heat and horror vacui, the heat expels the air and so creates a partial vacuum (H. B. Gottschalk, Strato of Lampsacus: some texts, Leeds, Leeds Philosophical and Literary Society, 1965, pp. 109-110, 147).

${ }^{100}$ The word ekthlibein, "squeeze out", seems to have been favoured by the atomists: see the 'Wortindex' to Diels-Kranz, op. cit., note 39 above, s.v.
} 


\section{Iain M. Lonie}

humours is simply left unexplained, the general assumption being that since it is possible for them to move about the body, they will do so unless they are otherwise prevented. This is one difference from Hoffmann's mechanism. Another, equally significant, is that the notion of any kind of elasticity in solid matter itself seems to be quite foreign to Greek thought before the Stoics.

The second part of the dissertation ( $\$ \S X V I I I-X X V I I I)$ is devoted to the explanation of health, disease, and the treatment of disease on mechanistic principles.

Hoffmann regarded his system of medicine as essentially a renewal of the tradition. What was the nature of this traditional novelty? A characteristically smooth argument can be discerned within the MRS. Hoffmann's purpose, as we have seen, was not to describe physiological and pathological doctrines for their own sake, but to establish the diagnosis and treatment of disease upon the new foundation of the anatomical and physiological discoveries of the preceding century. Hitherto, so Hoffmann argues, the practice of medicine has been unsystematic and empirical, a fact which has encouraged the proliferation of "hypotheses" in medicine and the conflict of physicians who based their treatment upon one or other of these hypotheses. Such conflict - as in Hippocrates' own time - merely causes scepticism among the lay public, in which the whole basis of the profession is brought into question. ${ }^{101} \mathrm{~A}$ sure and scientific pathology must rest on an understanding of the mechanism of the body. Recent discoveries have made such an understanding possible. Why is it, however, that little recent progress has been made in pathology, while anatomy, physics, botany, and chemistry have been striding ahead? The reason is that no one has correctly applied the discovery of the circulation to pathology and therapy. Physicians are still drawing false conclusions from the principles of the Ancients, principles long ago refuted and directly opposed to the facts of the circulation. ${ }^{102}$ The first true principle in medicine is Nature, or the perennial motion of blood and the humours. That is how Hippocrates - an honourable exception among the Ancients - understood it. ${ }^{103}$ Diseases arise through the disturbance of the vital motions of the circulation as the result either of spasm, the excessive constriction of the solid parts which accelerates the motion of the fluids, or of the opposite state of atonia. In this new conception of disease, all disease is an affection of the genus nervosum, and of the solid parts in general. This solid pathology replaces the pathology of the Ancients, who explained diseases by the corruption of humours. ${ }^{104}$

It cannot be denied that Hoffmann's explanations of the causes of particular diseases contained much that was new. So did his justifications for their treatment. His practice however remained largely within traditional lines. The traditional means are applied in the same circumstances as they always had been. ${ }^{105}$ Like Galenic

101 On "hypotheses" see MRS, tom. II, Proleg., cap. II, "De hypothesium medicarum in arte nostra damno"; and "De medicina ab omni hypothesi vindicanda" in suppl. 2, pars 1, 98-99. The Hippocratic passage which Hoffmann quotes is Regimen in acute diseases 8, Jones 2, 68-69.

102 MRS, tom. II, Proleg., cap. I, §xvii.

${ }^{103}$ MRS, tom. III, sect. I, cap. IV, §vii.

104 Ibid., §xlvi.

105 We must however allow for variations in the application of these means, which while they seem insignificant to us, may have appeared novel and unorthodox to contemporaries. Indeed, this should be a general principle in the history of therapeutics, which is largely the history of a craft knowledge. For this reason, earlier historians such as Sprengel, since their own practice was often governed by the same general 


\section{Hippocrates the iatromechanist}

physicians, Hoffmann laid great emphasis on regimen, in which he retained the traditional structure of the six non-naturals. ${ }^{106} \mathrm{He}$ gave qualified assent to the curative power of nature, particularly in fever. This was the consequence of his identification of nature with the vital force of the circulation. ${ }^{107}$ Fever is a variety of spasm, in which constriction of the fibres at the periphery causes a centripetal movement of the humours, which is resisted by the centrifugal movement of the circulation. But despite this solidist approach, the model for the pathology of fever is still to a large extent Galenic and humoral; and the continuous and intermittent fevers, the most important groups, are explained largely as they are in Galen, by a febrile matter, a mass of corrupted humour. ${ }^{108}$

In therapy too Hoffmann's principles are - inevitably - Galenic and Hippocratic. These principles are listed in MRS, tom. III, sect. II, cap. II: most of them are based directly upon familiar Hippocratic aphorisms, which Hoffmann cites.

Hoffmann is able to represent all this traditionalism to himself as "rational", i.e. mechanistic, because it can be formulated in terms of relationships between solids and fluids. Ultimately, however, pathology and therapy are referred to the same basis as they are in Hippocratic or Galenic medicine: a generalized humoralism. But it was the formulation which was important for Hoffmann. In one passage he describes disease as a disproportion or imbalance: "a great disturbance and alteration in the regulated proportion of motions in solids and fluids". ${ }^{109}$ Characteristically, the disproportion is

assumptions as the practice of the writers whom they discuss, are an indispensable guide.

106 Un the importance of the non-naturals in Hoffmann's system see King, op. cit., note 80 above, pp. 197 , 200; and cf. Temkin, op. cit., note 91 above, p. 102 and note 20. Hoffmann, in a chapter of the Prolegomena to MRS, 'De medicina eclectica', in which he selects what he regards as the best practical methods from the medicine of the past and the present, chooses from Galen primarily the use of the non-naturals and the practice of venesection (MRS, Proleg., cap. VI, §vi).

${ }^{107} \mathrm{See}$, for example, the context in which the dissertation De motuum febrilium indole ac sede repeats a favourite observation of Hoffmann's: "Hic enim sanguinis circulus est illa Hippocratis natura, morborum et potissimum febrium optima medicatrix." (Opera omnia, suppl. II, pars 2, p. 16). On the vis medicatrix naturae in Hoffmann, see Charles Daremberg, Histoire des sciences médicales, Paris, Baillière, 1870, vol. 2, pp. 944-946; and Neuburger, op. cit., note 57 above, pp. 62-65.

${ }_{108}$ The writings of Hoffmann on fever are extensive. See MRS, tom. III, sect. I, cap. IV, $\S \S x$ and xviii-xix; tom. IV, sect. I and sect. II, "Doctrinam de omnis generis febribus ... tradens"; Dissertatio de febrium intermittentium nova hypothesi (1694) (suppl. II, pars 2, pp. 17-22); De generatione febrium (1715) (ibid., pp. 1-9), which is a particularly useful compendium of Hoffmann's doctrines; De motuum febrilium indole ac sede (1723) (suppl. II, pars 2, pp. 10-16); and the very useful Tractatio brevis et luculenta de febribus (suppl. I, pars 1, pp. 298-313). There is a convenient definition of fever in MRS, tom. IV, sect. I. Proleg., §iii: it is "a spasmodic affection of the whole nervous and vascular system, combined with impairment of all the bodily functions, arising from a cause which irritates the nervous parts to a more intense contraction such that the vital fluids are first driven from the periphery of the body to the inward parts, the heart and the greater vessels; and then, by an increase in the systole of the heart and arteries, are driven rapidly outwards again through the narrower vessels, until the spasm relaxes, excretions follow, and so the fever ceases." Hoffmann's approach to fever is characteristically eclectic: although he gives it a nervous origin, being influenced in this by Borelli, the symptoms are explained and the treatment justified in humoral terms; e.g. the distinction between continuous and intermittent fevers is still associated, though in disguised form, with the venerable distinction between humours which putrefy intra vasa or extra vasa (e.g. De generatione febrium, §viii; Tractatio de febribus, p. 309).

109 "Magna mutatio et turbatio proportionis et ordinis motuum in solidis et fluidis" (MRS, tom. II, pars I, cap. II, \$111). The idea derives from Baglivi: see De fibra motrice cap. VI, "De aequilibrio solidorum cum solidis, fluidorum cum fluidis", where it is developed into considerable detail (Baglivi, op. cit., note 12 above, pp. 192-199). 
one of movements, not of quantities or qualities. Hoffmann uses the same formulation in the dissertation, and in section $\mathrm{XX}$ develops the concept of disease as a disproportion. It then becomes, as he says, "no difficult matter" to show that this was Hippocrates' concept also.

He first describes the formal cause of health, in a passage which begins grandiosely with a reference to "the eternal laws of motion". Referring to Borelli, he says that "every moving body loses from its own motion as much as it impresses upon the body with which it collides ... from which it follows that there is in nature a perpetual action and reaction of bodies". ( $\S$ XVII, p. 116.) In the case of the human body, there is a mutual interaction of solids and fluids: "and if these actions and reactions maintain a due proportion such that the fluids may be carried through the smallest channels with a free and moderate impetus, the formal cause of health (sanitatis ratio) is perfectly discovered" (ibid.). This is a particularly good example of Hoffmann's technique. He cites - from Borelli - a law of mechanics, which he then applies to a physiological process. The reader is given the impression that something has been explained in a new and revealing way, although on examination the explanation turns out to be banal. But from the mechanist point of view, what matters is that a theoretical structure has been provided for the quantification of such processes - even though this is never actually attempted.

The formal cause of disease corresponds to this formal definition of health; it is the loss of proportion in the interaction of fluids and solids ("aequilibrii solidorum ad fluida sublatio", $\S X I X$, p. 117). Hoffmann then identifies the proportion and disproportion of motions with the proportionate and disproportionate mixtures of humours or powers, by which health and disease are defined in Nature of man 4 (Jones 4.10-13) and Ancient medicine 14 (Jones 1.38-39). It is apparently sufficient that the equation of health with equilibrium should have been made by Hippocrates: we need not enquire too closely into what kind of equilibrium he meant. ${ }^{110}$

Hoffmann then cites a number of Hippocratic texts confirming the importance which Hippocrates attached to the six non-naturals in maintaining or upsetting this equilibrium. Both themes and texts are commonplace in traditional Hippocratic medicine: food, drink, and exercise (Regimen); climate and general environment (Airs, waters and places), particularly air (Airs, waters and places, Breaths, Nature of man). However, he also adds the unfamiliar Diseases 4, whose inclusion is interesting in view of its mechanistic tendency. On it Hoffmann comments: "The whole text deserves to be read: it explains with the utmost clarity how health comes about through the ingesta and egesta" ( $\$ X X I$, p. 118).

In XXVI he turns to therapy. He says, "To cure on mechanistic principles is nothing but the removal of the causes of disease by the appropriate remedies, and with the help of nature". Since the causes of disease are those which disturb the equilibrium, temperature, and movements of the body, rational method is to apply

\footnotetext{
110 There is a similar lack of nicety in the way in which two such disparate texts as Nature of man and Ancient medicine are here pressed into the service of rational medicine. For those who, like Mercuriali, were interested in such matters, Ancient medicine could not be genuinely Hippocratic, since it appeared to reject the theory of four elements which (it was supposed) was expounded in Nature of man (Mercuriali, Censura ..., op. cit., note 19 above, p. 15).
} 


\title{
Hippocrates the iatromechanist
}

counteracting remedies.

Here again Hoffmann is firmly within the tradition. Since Galen, "rational" medicine, which starts with a knowledge of causes, had been associated with the principle of treatment by contraries. ${ }^{111}$ But the link is already made in Breaths 1:

\begin{abstract}
Whoever knows the cause of the disease is able to apply what is beneficial to the body, because he knows what is opposed to the disease; for this form of the medical art is the one which is most in harmony with nature. For example, starvation is a disease (since we call "disease" anything which causes a man pain). Now what is the remedy for starvation? Whatever stops it, namely food. Starvation then is to be cured with food. Again, drink puts a stop to thirst, and evacuation cures repletion, and repletion evacuation, and pain is cured by the removal of pain. In a word, opposites are the cure of opposites. For medicine is subtraction and addition: subtraction of what is in excess, addition of what is lacking. He who does this best is the best physician, while he who falls most short of it falls most short of the art. (VI $90 \mathrm{Li}$.)
\end{abstract}

There are four distinct but related propositions in this text: (i) in order to treat effectively one must know the cause of the disease, because (ii) diseases are cured by whatever opposes their cause; (iii) this is the way of nature; and (iv) treatment by contraries is treatment by addition and subtraction. It was this last point in particular which engaged Hoffmann's attention. In one passage he sums up the essence of rational mechanistic therapy as the addition of what is lacking and the removal of what is superfluous. ${ }^{112}$ In other words, mechanistic therapy is quantitative even though health and disease reside in motion.

I believe that it is in this point - a point of practical medicine - that we come closest to the real nature of the appeal which the "physical" Hippocratic texts held for Hoffmann, and the real reason why it seemed plausible to him to interpret them mechanistically. It also helps us to identify and define a significant feature in Hippocratic mechanism.

The text in which the conception of medicine as subtraction and addition is developed most systematically is Regimen, one of Hoffmann's favourite texts. Although there is no reason to suppose that Regimen and Breaths are related, since they propound different physical theories, Regimen does illustrate each of the four propositions listed above. In the first book of Regimen, the author sets out in oracular language a general theory of physiology which is based on the cosmic elements of fire and water. These elements tend continually to encroach upon each other, and hence to upset the desirable state of equilibrium. The elaborate dietetic prescriptions of the remaining books are explained in terms of this general theory, and are intended to restore or preserve the particular form of equilibrium between the two elements which happens to be most appropriate to the constitution of each individual.

The continual encroachment and adjustment between the elements is a process in

111 The principle of contraria contrariis is given as one of the distinguishing characteristics of the logical or rational sect in Galen, De sectis ad eos qui introducuntur $3(\mathrm{I}, 69-72 \mathrm{~K}$.$) and in pseudo-Galen Introductio$ sive medicus 3 (XIV, $676 \mathrm{~K}$.). Cf. also De constitutione artis medicae 11 (I, $261 \mathrm{~K}$.). This follows from the fact that rational medicine proceeds from a knowledge of the phusis of man, or phusiologia, inquires into the causes of disease, and bases its therapy on these causes. For Galen himself, the disciple of Hippocrates, the principle is true without exception (De methodo medendi, xi, 12 (X, $767 \mathrm{~K}$.); In Hippocratis Epidemiorum VI, ii, 9 CMG V, 10, 2, 2, p. 67, 16-18). From Galen onwards, Hippocrates is universally spoken of as the founder of rational medicine, distinguished from his empirical predecessors by the inquiry into causes.

112 MRS, Proleg., cap. IV, §xi. See above, pp. 117-118. Cf. MRS, tom. III, sect. I, cap. IV, §iii. 
nature, which the art of the physician imitates. In a striking and often acute passage (1. xi-xxiv) the author describes the resemblances between the crafts, of which medicine is one, and the nature of man. Art imitates nature, both in its end and in the actual processes which it employs to achieve that end. In shoemaking, for example, "cobblers divide wholes into parts and make the parts wholes; cutting and stitching they make sound what is rotten. Man too has the same experience. Wholes are divided into parts, and from union of the parts wholes are formed. By stitching and cutting, that which is rotten in men is healed by physicians. ... Nature of herself knows how to do these things. ... In other respects too nature is the same as the physician's art" (1. xv, pp. 253-5 Jones). Similarly, carpenters working a pit-saw, one pushing and the other pulling, "are copying the nature of man" in the processes of respiration and the absorption of food (1. xvi, p. 255 Jones). The activity of builders (in making plaster and bricks) "is a copy of the diet of man; moistening the dry, drying the moist, they divide wholes and put together what is divided" (l. xvii). There are similar comparisons with the forging, tempering, and welding of iron by smiths; with the processes used by fullers, cooks, and basketmakers (who "turn the baskets round as they plait them; they end at the place from which they begin. The circuit (periodos) in the body is the same; it ends where it begins"); sculptors who "take from that which is in excess and add to that which is deficient" (1. xix-xxi, pp. 257-259 Jones).

As in Hoffmann's own conception, nature is inherent in these mechanical processes, this endless shifting around of quantities - adding and subtracting, cutting, shaping, mixing, wetting, and drying. Medicine itself consists of just such simple and straightforward operations. At the head of passages which Hoffmann chooses to illustrate Hippocrates' therapy, is one from Epidemics 6.2, 1 (V 276, 3-278, 2 Li): ${ }^{113}$

To dilate, or to constrict: in some cases, not in others. To expel some humours and dry others up; to add humours, here, but not there. To make thin the body, skin, flesh and other parts, or to make them fat: in some cases yes, in others, no. To smooth, or to roughen; to harden, or to soften: in some cases yes, in others, no. To stimulate, or to numb, and all other actions of this kind. To channel off; to draw in a contrary direction what yields, and to yield to what resists. To draw a humour that will not come, and to drain one that comes: to bring about what is similar, as pain checks pain.

Unlike things, if they tend upwards, discharge them downwards, and the opposite; as for instance venesection purges the head, if the blood is not drawn off rashly. ${ }^{114}$

All these processes are means of altering the texture or consistency of solid parts of the body, or of moving humours from one part to another. The underlying assumption is that the body is just that machine-like structure of solid and fluid parts which Hoffmann visualized. It is also an object, to which the physician's relation is exactly like that of any other craftsman to the material of his craft - something which can be pushed and pulled, crushed, and shaped. So far as that attitude is present in Hippocratic medicine, it is indeed "mechanical" in Hoffmann's sense. But its source lies in the simple technology of the Greek world, not in the sophistications of mathematics.

\footnotetext{
${ }^{113}$ Le Clerc also quotes this passage in his general account of Hippocratic therapy, and he precedes it with the passage on subtraction and addition (op. cit., note 54 above, p. 189).

${ }_{114}$ Galen uses the text as the occasion for a sermon on the principle of contraria contrariis (In Hippocratis Epidemiorum VI, ii, 1-9 op. cit., note 108 above, pp. 60-71). An orthodox Galenist might have quoted it as happily as Hoffmann. It is all the more interesting therefore that the setting which the dissertation gives it should bring out so sharply the "mechanistic" facet of Hippocratic medicine. Yet after all, when it comes to detail, there are many mechanistic features in Galenic medicine also.
} 